IZA DP No. 29

\title{
Causes of Changing Earnings Inequality
}

\author{
Dennis J. Snower
}

J anuary 1999 


\title{
Causes of Changing Earnings Inequality
}

\author{
Dennis J. Snower
}

Discussion Paper No. 29

January

IZA

P.O. Box 7240

D-53072 Bonn

Germany

Tel.: +49-228-3894-0

Fax: +49-228-3894-210

Email: iza@iza.org

This Discussion Paper is issued within the framework of IZA's research areas The Welfare State and Labor Markets and General Labor Economics. Any opinions expressed here are those of the author(s) and not those of the institute. Research disseminated by IZA may include views on policy, but the institute itself takes no institutional policy positions.

The Institute for the Study of Labor (IZA) in Bonn is a local and virtual international research center and a place of communication between science, politics and business. IZA is an independent, nonprofit limited liability company (Gesellschaft mit beschränkter Haftung) supported by the Deutsche Post AG. The center is associated with the University of Bonn and offers a stimulating research environment through its research networks, research support, and visitors and doctoral programs. IZA engages in (i) original and internationally competitive research in all fields of labor economics, (ii) development of policy concepts, and (iii) dissemination of research results and concepts to the interested public. The current research program deals with (1) mobility and flexibility of labor markets, (2) internationalization of labor markets and European integration, (3) the welfare state and labor markets, (4) labor markets in transition, (5) the future of work, and (6) general labor economics.

IZA Discussion Papers often represent preliminary work and are circulated to encourage discussion. Citation of such a paper should account for its provisional character. 
IZA Discussion Paper No. 29

January 1999

\section{ABSTRACT}

\section{Causes of Changing Earnings Inequality ${ }^{1}$}

This paper surveys major empirical regularities concerning changes in earnings inequality in Europe and the U.S. over the past 25 years. Next, it indicates which of these regularities can be explained within the competitive demand-supply framework of analysis and what is left unexplained. Finally, it considers the implications of organizational change as a possible rationale for recent inequality developments.

JEL Classification: D31, D33, D23, D24, D63.

Keywords: Inequality, income distribution, earnings, wage rigidities, skilled and unskilled workers, education, globalization, technological change, organizational change, labor supply, minimum wage, unionization.

Dennis J. Snower

Department of Economics

Birkbeck College

University of London

7 Gresse Street

London W1P 1LL

England

Tel.: +44-171-631-6408

Fax: +44-171-631-6416

Email: dsnower@economics.bbk.ac.uk

\footnotetext{
${ }^{1}$ I am grateful for important comments and suggestions by Jonathan Haskel, Robert Lawrence, Kevin Murphy, and Joyce Rogers.
} 


\section{Causes of Changing Earnings Inequality}

Analyzing the causes of earnings inequality is an area where the stakes are high. Earnings make up the lion's share of individual incomes ${ }^{2}$, and income inequality, when severe, is one of the most deleterious social and economic problems. It threatens a nation's social cohesion; by pitting people against one another, it puts a strain on democratic political processes. It is often associated with health problems, resentment, hopelessness, crime, and other social pathologies.

The debate about the causes of earnings inequality has momentous policy implications, which go to the heart of the divide between conservatives and liberals, between those who trust the free market mechanism and those who call for government intervention. If inequality is viewed as the price we must pay for economic efficiency, then the policy question is how much national income we are willing to sacrifice for a more equal division of that income. Yet if inequality is itself viewed as a form of inefficiency, then it becomes natural to search for policies that reduce both inequality and waste of economic resources. Our view about the appropriate policy response clearly depends on our interpretations of past economic events, and these interpretations are what we identify as the "causes" of inequality.

Mainstream economics has created a powerful and useful framework of thought to explain the evolution of earnings inequality. It may be summarized in two easy steps:

- First, changes in people's earnings may be understood as the outcome of a contest between supply and demand under perfect competition and perfect information. conditions. If the demand for a particular type of labor service rises relative to the supply of it, its earnings will rise; and conversely, if the supply rises relative to the demand, earnings will fall.

\footnotetext{
* I am deeply indebted to Jonathan Haskel, Robert Lawrence, Assar Lindbeck, Kevin Murphy, Alice Rivlin, June O'Neill, and Joyce Rogers for insightful comments.

${ }^{2}$ Earnings inequality plays a large role in determining other types inequality. In most OECD countries, the distributions of household incomes have tended to change in similar ways as the distributions of individual earnings. The increased earnings dispersion in the U.S. has been matched by increased dispersion of family income. There is a substantial and stable amount of earnings immobility many OECD countries (including the U.S.), implying that earnings inequality in a particular years gives some indication of earnings inequality over a much longer time span. (Atkinson, Bourguignon, and Morrison (1992) and OECD (1996) find that on average about two thirds of earnings inequality in any particular year is permanent, or very persistent across a large number of OECD countries.)
} 
- Second, if there are institutional rigidities, such as minimum wage laws, that prevent wages from adjusting, changes in labor supply relative to labor demand will lead to changes in unemployment rather than changes in earnings.

This framework of thought has worked well in accounting for some empirical regularities. Starting in the early 1970s and proceeding at a quicker pace since the early 1980s, the earnings of skilled people rose relative to those of unskilled ones, even though the supply of skilled labor also rose relative to the unskilled supply. From these observations particularly pronounced in the United States and the United Kingdom, but noticeable in other OECD countries as well - it is commonly inferred that the demand for skills must have risen faster than their supply. To explain why this relative demand shift occurred, one must find some major structural changes affecting the relevant economies over the past two decades but not before. Much of the economic literature has focused on three phenomena: globalization, deindustrialization and skill-biased technological change. Though fiendishly difficult to measure, all are capable of raising the demand for skilled relative to unskilled labor.

Furthermore, if we accept that wage rigidities are more common in the European Community than in the U.S. and the U.K., the rise in the demand for skilled relative to unskilled labor may be expected to generate more unskilled unemployment and less earnings in equality in the EC. This prediction is commonly thought to have been borne out by the evidence. Since the early 1970s unemployment in the EC has risen dramatically relative to that in the U.S. The people who suffered wage declines in the U.S. - the unskilled and the young - tend to be the ones who are unemployed in Europe. On this account, the European unemployment problem is commonly seen as the flip side of the U.S. earnings inequality problem.

The conventional supply-demand framework, operating under perfect competition and perfect information, has proved very fruitful in accounting for the evolution of inequality - so fruitful, that it has become commonplace to believe that inequality is determined by little else. This framework has utterly dominated the discussion of inequality in the media and policy-making circles.

The purpose of this article is to survey what can be explained within the conventional supply-demand framework, and also to examine what is left unexplained and where to look for possible answers. I believe that this framework has missed something important. It has 
blinded us to what will possibly come to be seen as one of the great transformations of postindustrial society. I argue that a constellation of recent organizational changes, to be called the Organizational Revolution, may be playing a major role in driving the observed changes in inequality. I believe that this transformation is as yet in its infancy; but once it comes to be recognized, it will shake the foundations of our economic understanding of inequality. At present, however, this transformation has been largely ignored in empirical economic analysis (although it has received spot-light attention in the business administration, management, and sociology literatures), and thus the discussion of the Organizational Revolution must remain conjectural and suggestive for now.

While the empirical evidence on inequality is reasonably uncontroversial, the "causes" of inequality are not objectively observable. Rather, they are interpretations based on our implicit patterns of thought. This article presents some challenges to the conventional interpretations and offers a new interpretation in response.

The article is organized as follows. Section 1 discusses major empirical regularities that are easy to explain within the conventional supply-demand framework under perfect competition and perfect information. Section 2 describes that framework. Next, Section 3 considers important empirical regularities that are harder to explain in the conventional way. Section 4 goes beyond the conventional analysis to examine the implications of the Organizational Revolution. Finally, Section 5 concludes. Readers interested in a straightforward survey of the mainstream literature should read till Section 3 and then stop; those acquainted with the literature and searching for new ideas should skip straight to Section 4.

\section{Observations that are Easy to Explain Conventionally}

The conventional framework is able to account for a various empirical regularities concerning earnings inequality in the U.S. I begin by summarizing the best-known of these "stylized facts" and then turn to their conventional interpretation.

Fact 1: U.S. Earnings Dispersion: From the beginning of the 1950s till the mid-1970s, the U.S. distribution of real earnings was stable; since then earnings dispersion has increased rapidly.

Prior to the mid-1970s, the dispersion of real personal earnings (measured, say, by the difference between weekly earnings at the $90^{\text {th }}$ and $10^{\text {th }}$ percentiles) was so stable that it was commonly considered to be one of the famous constants of economics. ${ }^{3}$ But then, in the

\footnotetext{
${ }^{3}$ See, for example, Lampman (1971, p. 47).
} 
second half of the 1970s, something happened. In terms of hourly, monthly and yearly earnings, the rich began getting rapidly richer and the poor even more rapidly poorer. Earnings dispersion started drifting upwards in the 1970s and increased at a much faster rate since the early 1980s. ${ }^{4}$ This has been an astonishingly pervasive phenomenon. It has affected men's earnings and women's earnings; it has widened the pay differential among and within occupational groups, among and within groups with different lengths of job tenure, and among and within different educational groups; it has fanned out the incomes of the rich and those of the poor. In fact, the entire distribution of U.S. earnings has been pulled apart over the past two decades: the higher people's percentile rank in this distribution, the faster their real earnings grew; the lower their rank, the faster their earnings declined.

Thus U.S. productivity growth since the productivity slow-down of the mid-1970s has not been spread evenly throughout the working population. Till the mid-1970s, the real earnings of the rich and poor tended to grow in line with productivity. But over the two decades from the mid-1970s to the mid-1990s, only about a fifth of the U.S. working population participated in the impressive climb of national income. The highest earners have not just captured all the productivity gains; their earnings have grown at the expense of more than three quarters of all U.S. males. The widening U.S. earnings dispersion between the mid-1970s to the mid-1990s was due more to a fall in male earnings at the bottom of the distribution than to a rise at the top. ${ }^{5}$ Since 1996, however, the fall in the earnings of the poor appears to have been arrested, and both the rich and poor have witnessed earnings growth.

It is important to note however that, with the exception of the U.K., the other OECD countries did not share the U.S. experience of a rapid and persistent widening of the earnings distribution. In the rest of the advanced industrialized world this trend was either non-existent (as in Germany and Italy) or relatively modest.

Fact 2: The U.S. Skill Premium: By several alternative measures of skill, the earnings of skilled workers have risen relative to those of unskilled workers over the past two decades. (a) The Education Premium: Since the mid-1970s in the U.S., the earnings of the less educated have fallen rapidly behind those of the more educated. (b) The Experience Premium: The earnings of older people relative to younger people in the U.S. were roughly constant till the beginning of the 1970s and have increased rapidly since then. (c) The Non-

\footnotetext{
${ }^{4}$ Two admirable surveys of this development are Levy and Murnane (1992) and Gottschalk and Smeeding (1997).

5 According to Topel (1997), males in the bottom decile of the U.S. earnings distribution experienced a staggering $20 \%$ drop since 1970 .
} 
Production Premium: The wages of U.S. non-production workers relative to those of production workers in manufacturing have risen substantially since the 1970s.

The rise in the relative wages of skilled to unskilled workers, occurring roughly alongside a rise in the relative employment of skilled to unskilled workers, has been widely documented for the U.S. ${ }^{6}$ and other OECD countries. ${ }^{7}$

The Education Premium: The U.S. college premium (the difference between the average weekly earnings of college graduates and those of a high school graduates) was reasonably stable throughout the 1960s, fell in the first part of the 1970s, and has risen dramatically since the early 1980s. The increase in the U.S. college premium arose more because the earnings of the less educated people fell than because those of more educated people rose. ${ }^{8}$

The Experience Premium: "Experience" is commonly measured as age minus years of education, minus 6; thus the experience premium is the difference between the weekly earnings of people who have been in the labor force a long time and those who have been there a short time. For men, the experience premium increased markedly from the early 1970s to the mid-1980s and has leveled off since then. Women, however, have witnessed a continuous rise of their experience premium since the early 1970s, with the fastest rate of increase coming in the 1980s and 1990s. ${ }^{9}$ The rise in the experience premium in the first half of the 1970s helps explain why earnings dispersion increased over that period, despite the fall in the education premium at that time.

The Non-Production Premium: The ratio of wages of U.S. non-production workers to those of production workers in manufacturing ${ }^{10}$ increased from 1.53 in 1979 to 1.64 in 1990. It has been argued that the distinction between non-production and production workers corresponds reasonably well to the commonly drawn divide between skilled and unskilled workers on the basis of occupation. ${ }^{11}$

Fact 3: The U.S. Supply of Skills: Over the entire postwar period in the U.S., the supply of college graduates has increased relative to the supply of those with only a high school

\footnotetext{
${ }^{6}$ Blackburn, Bloom, and Freeman (1990), Bound and Johnson (1992), Katz and Murphy (1992), Murphy and Welch (1992).

${ }^{7}$ Davis (1992), Freeman (1988), Freeman and Katz (1994), Katz and Ravenga (1989), Katz, Loveman and Blanchflower (1995), Machin (1996), OECD(1996).

${ }^{8}$ The average real weekly earnings of college graduates rose by 5\% between 1979 and 1994, while those of high school graduates declined by $20 \%$. See Gottschalk (1997, p. 30).

${ }^{9}$ See Gottschalk (1997, p. 32).

${ }^{10}$ Berman, Bound, and Machin (1997).

${ }^{11}$ Berman, Bound, and Griliches (1994) and Berman, Bound, and Machin (1997).
} 
degree. The relative supply has grown particularly fast in the 1970s and 1990s, whereas the corresponding relative earnings have grown particularly fast since the 1980s. Similarly, the supply of non-production workers has grown relative to the supply of production workers.

Between 1950 and 1970, the relative supply (of college graduates versus high school graduates) grew roughly in line with productivity, at around $2.4 \%$ per annum. College enrollments increased rapidly in the 1960s, spurred by educational deferments from military service. Thus in the 1970s the relative supply speeded up to $4.8 \%$. Between 1979 and 1989, it slowed back down to $2.7 \%$. During this period the college premium widened dramatically, which probably induced more people to get college degrees. Accordingly, between 1989 and 1993, the relative supply of college graduates versus high school graduates speeded up again to $3.3 \%$ per annum. ${ }^{12}$

What is striking is that this massive increase in the supply of college graduates did not keep the college premium down. On the contrary, between 1973 and 1993, the average college premium increased by close to $60 \%$, and for recent college graduates (with up to 5 years of experience) it doubled. ${ }^{13}$ Equally striking is that the earnings of high school graduates fell during that period, even though their relative supply was dwindling quickly.

By the same token, the rise in the earnings of non-production workers relative to production workers between 1979 and 1990 occurred despite a significant rise in the ratio of non-production employment to total employment in manufacturing (from 0.27 in 1979 to 0.32 in 1990).

By contrast, the increase in the labor supply that occurred in the 1970s, when the baby boom cohort joined the labor force, was associated with a fall in their earnings relative to older people. ${ }^{14}$

One might have expected that the effects of labor supply on earnings would manifest themselves most clearly at the local level, such as when immigrants enter particular geographic areas and compete with native workers there. But most studies of immigration to the U.S. suggest such influences are at best weak. The available evidence appears to indicate that this is so on account of the considerable labor mobility of native Americans; in particular, the inflow of immigrants is offset by the outflow of natives. ${ }^{15}$

Next, there are two stylized facts concerning the inequality implications of institutional wage rigidities.

Fact 4: The Minimum Wage and the Wage Distribution: In countries where the minimum wage is a significant proportion of labor earnings, the lower tail of the wage distribution tends to be compressed at the minimum wage.

Fact 5: Unionization, Centralized Bargaining and the Wage Distribution: In countries with high rates of unionization and centralized bargaining tend to have greater wage equality, other things being equal. However, there is a pronounced trend toward decentralized wage bargaining in many OECD countries.

\footnotetext{
${ }^{12}$ See Johnson (1997, p.43).

${ }^{13}$ See Johnson (1997, p. 43).

${ }^{14}$ See Welch (1979) and Berger (1985).

${ }^{15}$ See, for example, Altonji and Card (1991), Card (1990), and Filer (1992).
} 
Between 1979 and 1988 the U.S. minimum wage fell from over 40\% to just over $30 \%$. In 1979, when the minimum wage was a significant fraction of average wages, a comparatively large proportion of low-wage earners was concentrated around the minimum wage. This was particularly true for women, who tend to have lower wages than men. But by 1988, the minimum wage ceased to be a constraint on most people's wages, so that a much smaller proportion of low-wage earners was affected by it. ${ }^{16}$ A number of authors have suggested that the fall in the U.S. minimum wage exerted an important influence on earnings dispersion. ${ }^{17}$ A similar claim has been made about the abolition of the minimum wage in the U.K. ${ }^{18}$

The minimum wage appears to have had little influence on the U.S. college premium (the earnings difference between college and high school graduates) particularly regarding full-time males. The reason, of course, is that the minimum wage affects mainly the lowest wage earners, and only a small proportion of full-time male workers with a college or high school degree fall into this category.

The U.S. unionization rate remained reasonably stable throughout the 1960s and 1970s, then fell sharply over much of the 1980s, and stabilized in the 1990s. ${ }^{19}$ Thus the unionization rate fell fastest during the decade in which male wage dispersion widened most. Several authors have claimed that union density significantly reduces wage dispersion and low-wage employment. ${ }^{20}$

Unionization appears to have two salient influences: it compresses the wage structure and raises the average wage. ${ }^{21}$ The first effect reduces wage inequality and the second raises it (provided that unionized workers are highly paid relative to non-unionized workers.) For men, the first effect appears to dominate the second. ${ }^{22}$ In that event, the observed fall in U.S. unionization during the 1980s could help account for the widening wage dispersion over that period. This fall, however, does not appear to have had a significant influence on female wage distribution. This is perhaps not surprising since only a small proportion of women workers are unionized.

\footnotetext{
${ }^{16}$ In 1979, $12 \%$ of workers in the Current Population Survey earned no more than the minimum wage; and by 1988 the number had fallen to $4 \%$.

${ }^{17}$ See Fortin and Lemieux (1997, p.81), Mishel and Bernstein (1994), Dinardo, Fortin and Lemieux (1996).

${ }^{18}$ See Machin and Manning (1994).

${ }^{19}$ See DiNardo, Fortin, and Lemieux (1996) and Hirsch and Macpherson (1996).

${ }^{20}$ See Freeman (1993), Mishel and Bernstein (1994), Dinardo, Fortin, and Lemieux (1996).

${ }^{21}$ See, for example, Lewis (1986).

22 See Freeman (1980).
} 
Aside from minimum wages and unionization, there are of course a wide variety of other institutional constraints that could keep wages from responding to changes in supply and demand. Welfare benefits may give rise to a wage floor. There is some evidence that industries which were deregulated in the 1970s and early 1980s - such as communications, energy, finance, and transportation - experienced a more pronounced widening of the male distribution of hourly earnings than the other industries. Although the deregulated industries had relatively high unionization rates and suffered relatively steep declines in unionization, some of the deregulation effect on earnings appears to be independent of unionization, but this effect is comparatively small. ${ }^{23}$

Finally, it has often been observed that OECD countries with highly centralized wage bargaining institutions tend to have experienced at most small changes in earnings inequality, compared with countries where bargaining is decentralized. For example, earnings inequality in Germany and the Nordic countries has increased much less over the past two decades than in the U.S. and the U.K.

However, there has been a well-documented drift towards more decentralized wage bargaining in many OECD countries. ${ }^{24}$ For instance, both the U.S. and the U.K. have experienced drops in multi-employer wage agreements in favor of company and plant-level bargaining since the early $1980 \mathrm{~s},{ }^{25}$ Germany and Italy have also witnessed a gradual rise in plant- and workshop-level bargaining over this period. ${ }^{26}$ Although these developments may well be influenced by the forces of globalization and technological change, there is little evidence that this influence in strong. ${ }^{27}$

\section{The Conventional Framework of Thought}

The conventional framework offers a starkly simple explanation for many of these phenomena. The framework is claimed to be particularly appropriate for the U.S. economy, which is commonly deemed to be largely free of institutional obstacles to wage adjustment, so that wages and employment can respond flexibly to supply and demand, as approximated by conditions of perfect competition and perfect information.

\footnotetext{
${ }^{23}$ See Fortin and Lemieux (1997, p. 85-6). Fair employment practice laws and regulations on overtime premia could be potentially important as well, but since they changed little over the 1980s, they are usually not given much attention as determinants of increasing U.S. inequality.

${ }^{24}$ Katz (1993) provides an excellent survey of this development.

${ }^{25}$ See, for example, Marginson et al. (1988), Millward and Stevens (1986), Millward et al. (1992), Katz and Kochan (1992), Parker and Slaughter (1988), and Turner (1991).

${ }^{26}$ Thelen (1991), Turner (1991), Windolf, EIRR (1992), and Locke (1992).
} 


\section{2a. Supply and Demand}

For simplicity, let us divide the labor force into two groups, the "skilled" and "unskilled" workers. In line with the previous discussion, "skills" may be interpretted in terms of educational attainment, experience, or occupation. In the conventional framework, the wages of the skilled and unskilled workers correspond to their productivities, which in turn depend on the available production technologies and the supplies of these workers. This portrayal of the labor market is illustrated in Figure 1.

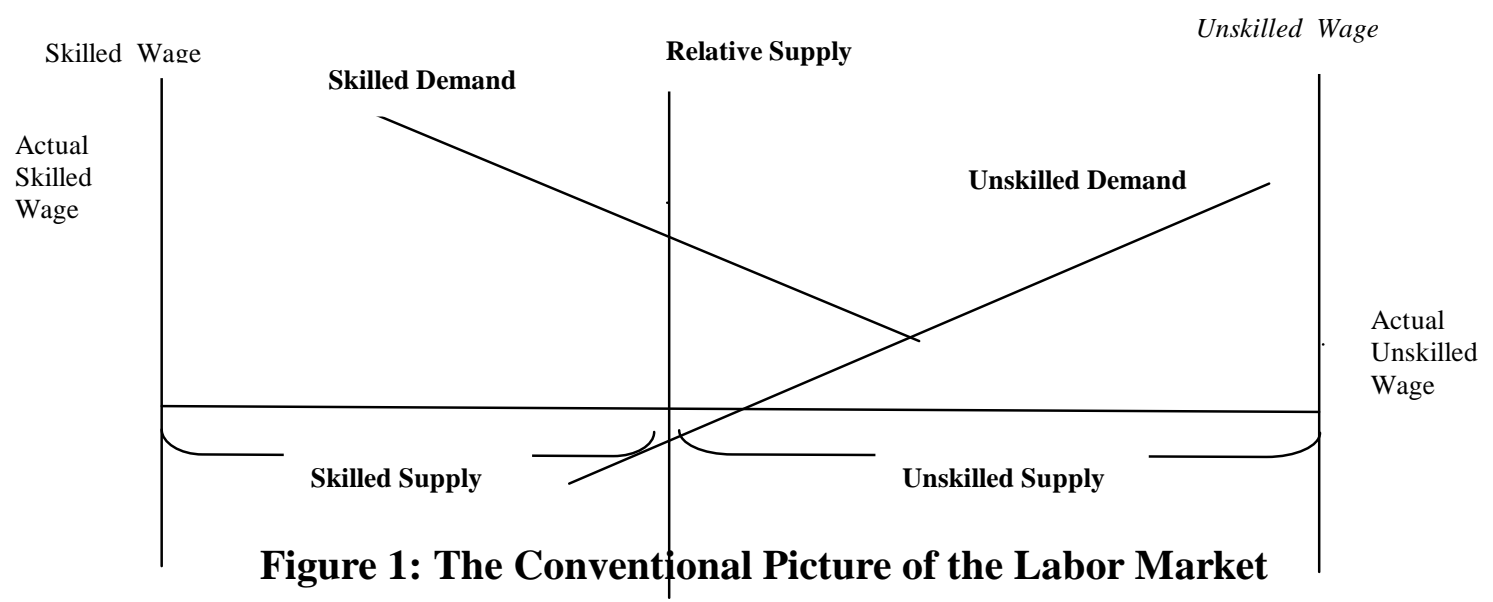

The relative supply curve is a vertical line that shows how the workforce is divided into skilled and unskilled people. ${ }^{28}$ The market for skilled labor is pictured on the left side of the figure. The demand curve for skilled labor slopes downwards from left to right (indicating that as the skilled wage falls, the demand for skilled labor rises); and the skilled labor supply is given by the relative supply curve, measured from left to right. The intersection between the demand and supply curves for skilled labor determines the actual skilled wage.

Similarly, the market for unskilled labor is depicted on the right side of the figure. The unskilled demand curve slopes downwards from right to left; and the unskilled labor supply is given by the relative supply curve, also measured from right to left. The actual unskilled wage is given by the intersection between the demand and supply curves for unskilled labor.

If "skill" is evaluated in terms of educational attainment, then Fact 3 implies that the U.S. relative supply curve has been shifting to the right over the postwar period. Had there been no shifts in the demand for skilled and unskilled labor, the rightward shift of the relative supply curve would have reduced the skilledunskilled wage differential. The rise in the supply of skilled labor would have driven the skilled wage down, and the fall in the supply of unskilled labor would have pushed the unskilled wage up, as shown in the following figure.

\footnotetext{
${ }^{27}$ Freeman and Gibbons (1993) argue the increasing volatility in local labor market conditions have played an important role.

${ }^{28}$ For simplicity, we assume that the aggregate supply of labor is constant, which is a reasonable approximation for many OECD countries. Clearly, a sufficiently large rise (fall) in the aggregate labor supply could lead to a reduction (increase) in both skilled and unskilled wages. Furthermore, we assume that the supplies of skilled and unskilled labor do not depend on wages. Relaxing this assumption would not affect the main substance of our analysis.
} 


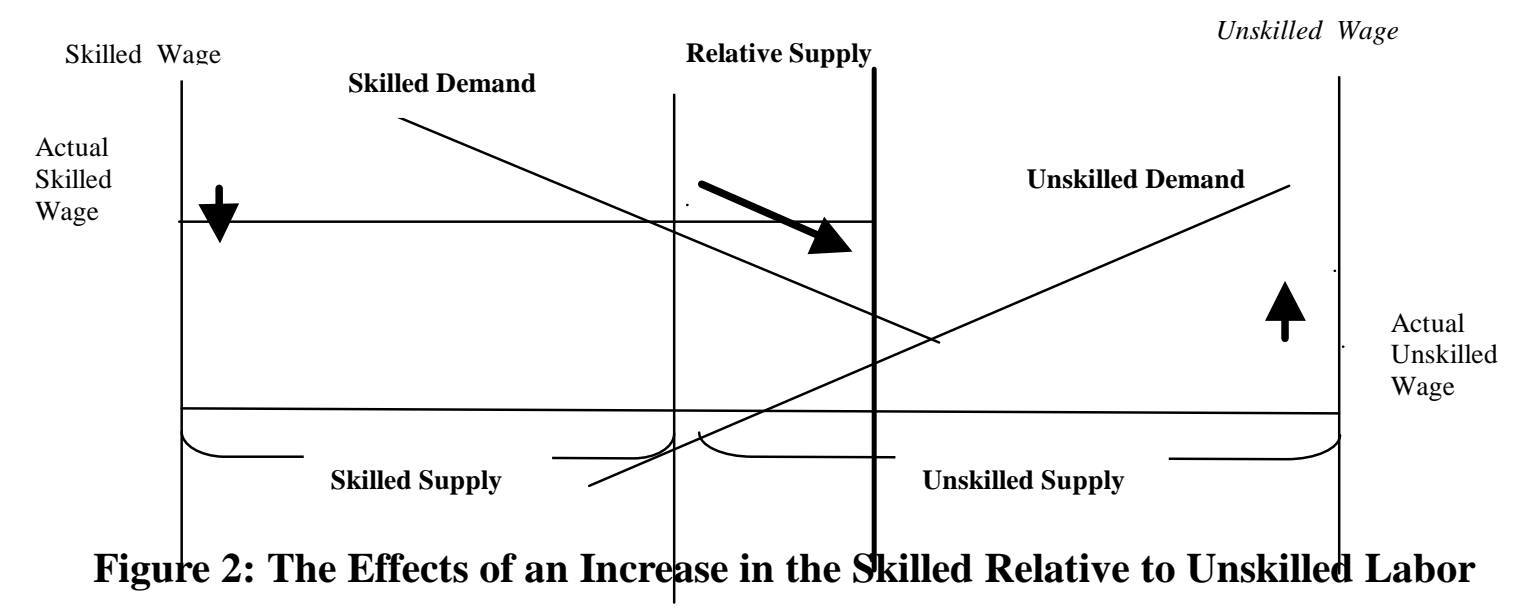

But as Fact 2 indicates, this did not happen in the U.S. Instead, the wage differential between the skilled and unskilled has widened between the mid-1970s and the mid-1990s. As noted, the widening took the form of a modest rise in the skilled wage and a large fall in the unskilled wage. In the light of the conventional framework, these changes could only have occurred if (a) the skilled demand curve shifted up and (b) the unskilled demand curve shifted down, as illustrated in the following figure:

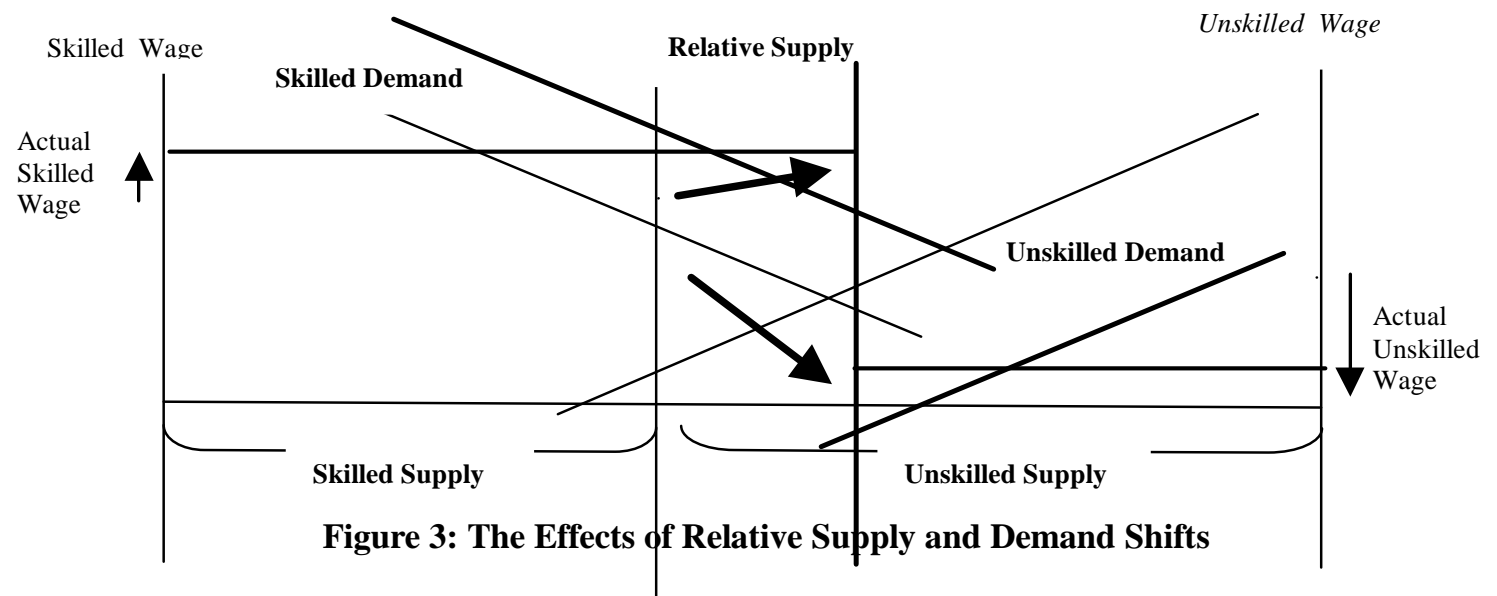

Since the skill differential widened, the demand shift must have dominated the supply shift. And since the widening involved more of a fall in the unskilled wage than a rise in the skilled wage, the demand for unskilled workers must have shifted down by more than the demand for skilled workers shifted up.

Since 1996 the wages of both skilled and unskilled workers appear to have been increasing. Consequently, while the demand for skilled labor must have continued to drift 
upwards faster than the supply, the demand for unskilled labor must have fallen at a slower pace or even have reversed itself.

In this way the relative demand shift (for skilled versus unskilled workers) is inferred from the observed changes in the relative wage. ${ }^{29}$

Within this context, we expect to find that variations in the relative supply lead to inverse movements in the relative wage (controlling for changes in relative demand). For example, when the relative supply of college-educated people (versus those with only a high school degree) expanded sharply in the 1970s, we expect to see a drop in the college wage premium. And when the growth of college graduates slowed in the following decade, we expect the college premium to rise again. Sure enough, this is what happened. Along the same lines, the fall in the U.S. education wage premium (of high school graduates relative non-graduates) that occurred in the early twentieth century may be attributed to the sharp rise in the proportion of high school graduates over that period. ${ }^{30}$ Similar responses of the relative wage to the relative supply have been reported for other countries. ${ }^{31}$

What is emphasized in the conventional analysis is that the relative demand for skills must have increased faster than the relative supply over the past two decades. Accordingly it is common to picture the labor market in much simpler terms than in the figures above: in a diagram containing the ratio of skilled to unskilled wages on the vertical axis and the ratio of skilled to unskilled employment on the horizontal axis, a downward-sloping demand curve is shown to shift outwards faster than a vertical supply curve. But this picture obscures an interesting phenomenon captured in the figures above: a falling demand for unskilled workers that dominated the rising demand for skilled workers for more than two decades, and then

\footnotetext{
${ }^{29}$ The standard formula that is used for this purpose is $g_{w}=(1 / e)\left(g_{d}-g_{s}\right)$, where $g_{w}$ is the growth of the relative wage (for skilled versus unskilled workers), $g_{d}$ and $g_{s}$ are the growth in relative demand and supply (respectively), and $e$ is the elasticity of substitution between skilled and unskilled labor (the responsiveness of relative employment to a change in the relative wage). In other words, if relative demand grows faster than relative supply $\left(g_{d}>g_{s}\right)$, the relative wage increases $\left(g_{w}>0\right)$. Furthermore, the more responsive is relative employment to the relative wage, the less the relative wage will move when there is a change relative demand or supply. Economists have data on changes in the relative supply, $g_{s}$ (i.e. changes in the relative numbers of people in specific education and experience groups) and changes in the relative wage, $g_{w}$. They also have independent estimates of the elasticity of substitution (e). (For example, Katz and Murphy (1992) estimate the elasticity of substitution between U.S college and high school graduates to be about 1.4 , so that a $10 \%$ increase in the ratio of college graduates to high school graduates reduces the college wage premium by about $7 \%$.) From these statistics, they can use the formula above to infer the changes in relative demand, $g_{d}$.

${ }^{30}$ See Goldin and Katz (1996).

${ }^{31}$ For example, Edin and Holmlund (1995) argue that educational upgrading during the early 1970s in Sweden was associated with the marked decline in the college wage premium. Kim and Topel (1995) suggest that the halving of the return to a college education in Korea between 1972 and 1989 was due to the increase in the relative supply of college graduates.
} 
moderated or reversed itself. This phenomenon, it turns out, is difficult to explain with the conventional tools.

For the moment, however, let us consider the conventional rationales for why the demand for skilled relative unskilled labor should have increased faster than the corresponding supply. Whatever happened, we know that the demand shifts had little to do with the business cycle. ${ }^{32}$ Much of the economic literature on inequality has focused on three, somewhat interrelated sources of demand shifts: globalization, deindustrialization and technological change. We now consider these phenomena in turn.

\section{2b. Globalization and Deindustrialization}

Since the 1960s the U.S. has become increasingly integrated in the global economy, as a variety of factors ${ }^{33}$ led to a gradual increase in internationally traded goods and services and international capital flows. In this global economy, according to the globalization hypothesis, skilled labor is relatively abundant in the U.S., while unskilled labor is relatively abundant in many of America's trading partners. Thus, as international trade opens up, it is worthwhile for the U.S. to specialize in the production of goods and services that make relatively intensive use of skilled labor and to import goods and services that are intensive in unskilled labor. In this process, the U.S. experiences an increased demand for skilled labor and a reduced demand for unskilled labor. America's trading partners, by the same logic, must experience the opposite.

The basic idea is that when there is incomplete specialization - so that each country produces all the available goods - global markets for goods tend to create global markets for labor (and other factors of production) used to produce these goods. Thus, under international trade, wages come to depend on global demands and supplies of labor rather than on domestic demands and supplies. Just as trade tends to equalize the prices of each good in different countries (measured in terms of a particular currency), it also tends to equalize

\footnotetext{
${ }^{32}$ Although earnings inequality has tended to fall during cyclical downturns and rise during upturns, this influence has been slight in comparison with the trend rise of earnings inequality since the mid-1970s. See, for example, Gottschalk (1997, p. 27).

${ }^{33}$ These factors include - reductions in tariff and non-tariff barriers (achieved in part through GATT, NAFTA, and WTO agreements), increased flows of foreign direct investment and technology transfers, advances in transport, pro-trade development strategies by less developed and emerging economies, and the absence of major wars.
} 
factor prices throughout the world. ${ }^{34}$ In this context, the wages of unskilled workers in the U.S. are set in Beijing, so to speak. ${ }^{35}$

It is important to observe that factor price equalization is driven by product price equalization, not by the size of trade flows. So even if U.S. trade with third world countries is small, the threat of imports from the third world keeps the prices of domestic goods at internationally competitive levels and thereby keeps the wages for each skill group equalized across countries as well. But this framework of analysis is not well suited to explaining the rise in the demand for skilled labor and the fall in the demand for unskilled labor. For the U.S. economy has been open to international trade for a long time, and it is the existence of these trade flows - not their magnitude - that are the dominant influence on wages when there is factor price equalization.

On the other hand, when there is complete specialization - so that countries export goods that are not produced abroad and import goods that are not produced domestically then wages are determined by domestic demands and supplies of labor. Moreover, when an expansion of international trade leads a country towards greater specialization in skillintensive goods, then the unskilled workers are driven into the non-tradable sectors. There, their wages are determined by their domestic productivity or wage floors existing in the country. In the U.S., therefore, the wages of unskilled workers are set in McDonald's rather than in Beijing ${ }^{36}$. Under these circumstances, the factor content of international trade matters for earnings inequality, for through rising exports some of the country's domestic labor supplies are in effect flowing abroad, reducing the effective supply of skilled labor for domestic production and raising skilled wages.

Over the past three decades there has indeed been a significant expansion of U.S. trade activity. ${ }^{37}$ In 1970, U.S. exports plus imports comprised $12 \%$ of gross domestic product; but by 1990, it comprised $22 \%$. Admittedly, most of this trade is with other advanced industrialized countries, making comparable use of skilled and unskilled labor. But trade with the less developed countries has expanded as well. In 1970, 14\% of U.S. imports

\footnotetext{
${ }^{34}$ This is a tendency rather than an actual outcome, since the precise equalization of all factor prices is achieved only under very special, unrealistic assumptions, e.g., as noted, incomplete specialization and identical technologies and tastes across countries. Some trade economists suggest that the tendency toward factor price equalization may be quite limited (e.g. Bhagwati and Dehejia (1994)) while others regard it as a dominant force (e.g. Leamer (1984)).

35 This idea is captured in the title of Freeman (1997).

36 This formulation is due to Robert Lawrence, who contributed valuable insights to this section.

${ }^{37}$ See, for example, Freeman (1997).
} 
came from these countries; but by 1990, 35\% did. The exports of most OECD countries do appear to make more intensive use of skilled labor (measured in terms of education) than their imports. OECD imports of manufactured goods from less developed countries have increased considerably. ${ }^{38}$

Closely related to the globalization hypothesis is the deindustrialization hypothesis. It asserts that the widening earnings dispersion in the U.S. and some other advanced industrialized countries is due to the decline of the manufacturing sector (containing many low-wage workers) and the rise of the high-wage service sector. These changes may in turn have be driven by globalization and other causes.

Historical experience - particularly the effects of trade during the Industrial Revolution attests to the power globalization and deindustrialization on the geographic pattern of specialization and consequent movement in earnings. Over the course of the nineteenth century, Great Britain was transformed as it specialized in industry (where it had a comparative advantage) and left agriculture increasingly to its colonies. The result was a rapid rise in the earnings of industrialists and machine operatives, the proliferation of unskilled, sweatshop labor, and the ruination of many British farmers who were unable to compete with the agricultural produce pouring in from abroad. On the other side of the coin, the British colonies experienced a massive deindustrialization. At the beginning of the nineteenth century, India was a prominent exporter of textiles to Britain; by the end of the century, it was importing three-quarters of its textiles from Britain. The fear of deindustrialization in some of today's advanced market economies may have its origins in these past experiences of globalization. ${ }^{39}$

Nevertheless, the deindustrialization and globalization hypotheses have run into some serious empirical difficulties, and thus many economists believe that they account for only little of the widening U.S. earnings dispersion since the mid-1970s. ${ }^{40}$

There is no doubt that manufacturing has declined in favor of services in the U.S. and many other OECD countries. What is at issue is whether these changes could have been responsible for the massive increase in the demand for skilled relative to unskilled workers over the past two decades. Most economists think not. The observed sectoral changes do

\footnotetext{
${ }^{38}$ See, for instance, OECD (1994), Wood (1994).

${ }^{39}$ See Cohen (1998) for a stimulating account of these events.

${ }^{40}$ However there is no consensus on this issue. For a dissenting view, see Wood (1994).
} 
imply a rise in the wages and employment of skilled workers at the expense of unskilled

workers, but the implied movement is much smaller than what we have observed. ${ }^{41}$

The globalization hypothesis faces a raft of specific difficulties: ${ }^{42}$

The ubiquitous rise in the demand for skills:

- If the hypothesis were correct, then the rise in the demand for skilled labor in the skill-abundant countries (such as the U.S.) would be matched by a rise in the demand for unskilled labor in the countries with abundant unskilled labor (such as China, India, and the Mexico). In fact, however, the demand for skilled relative to unskilled labor appears to have risen virtually everywhere.

- Furthermore, as the wages of unskilled workers fell relative to skilled workers in the U.S., one would have expected unskilled employment to have risen in the non-traded goods sectors, as firms there substitute the progressively cheaper unskilled labor for the progressively more expensive skilled labor. But that didn't happen. In most sectors - whether tradable or non-tradable - skilled employment has grown at the expense of unskilled employment.

Problems of timing:

- U.S. trade as a share of gross domestic product increased rapidly during the 1970s and leveled off somewhat after that. But the dramatic increases in U.S. inequality didn't start occurring until a decade later.

- The increase in the demand for skilled relative to unskilled labor, inferred from the conventional analysis, has proceeded at a reasonably steady pace since the 1950s, and accelerated slightly in the 1980s and 1990s. If globalization was the main force driving the relative demand shifts, those shifts would not have become prominent until the 1970s.

Little labor mobility between the tradable and non-tradable sectors:

- Not enough unskilled people have shifted from the tradable to the non-tradable goods sectors to account for the downward shifts in demand for U.S. unskilled labor (inferred from the changes in earnings differentials, along the lines discussed above).

Changes in the composition of output:

- The globalization hypothesis (like the deindustrialization hypothesis) implies that changes in the wage structure are driven by changes in the composition of product demands (e.g. a rising demand for goods intensive in skilled relative to unskilled labor). However, most empirical studies have found that these compositional effects are far too weak to account for the observed changes in earnings dispersion. ${ }^{43}$

The importance of domestic labor supplies:

- In the presence of factor price equalization, the wages of skilled and unskilled labor are determined in the global market, and thus changes in domestic labor supplies (which have a negligible influence on global labor supplies) have no effect on the domestic wage structure. But, as noted, changes in the age structure of the U.S. population are correlated with changes in the experience wage premium, and changes in the supply of college graduates relative to those with only a high school degree are associated with changes in the education wage premium.

The small trade share:

- As noted, only a small part of U.S. trade is conducted with low-wage countries. Of course a small trade share could have still have a strong impact on wages and prices, provided that there is enough competition between the U.S. and its low-wage trading partners. But only a very small percentage of the U.S. labor force produces goods that are in competition with low-wage imports.

Loss of rents:

\footnotetext{
${ }^{41}$ See, for example, Murphy and Welch (1993, p. 126) and Berman, Bound, and Griliches (1993).

${ }^{42}$ For an excellent overview of important difficulties, see Lawrence (1996).

${ }^{43}$ For example, Katz and Murphy (1992), Kim and Topel (1995), Murphy and Welch (1993), Topel (1993).
} 
- The drop in the wages of unskilled people does not appear to be explicable by a tradeinduced loss economic rents by workers who previously had bargaining power (e.g. because of unionization and industrial concentration). ${ }^{44}$

On these various counts, support for the globalization hypothesis has been ebbing in the economics profession.

\section{2c. Technological Change}

In comparison with the globalization and deindustrialization, the technological change hypothesis usually gets a smooth ride in the economics profession and the news media. But closer inspection reveals that not all well on this front either.

The technological change hypothesis asserts that the improvements in technologies since the mid-1970s have been primarily "skill-biased," that is, they have increased the productivity of skilled, rather than unskilled, workers. ${ }^{45}$ Only skilled workers, it is claimed, have the ability to take advantage of the recent technological advances.

If that were all, the hypothesis would account for the increased demand for welleducated workers in the U.S., but not for the far larger fall in the demand for the lesseducated ones. To do that, researchers have distinguished between intensive and extensive skill-biased technological change. ${ }^{46}$ Intensive change helps the skilled workers and leaves the unskilled workers untouched, while extensive change enables the skilled workers to take over the jobs of the unskilled ones, so that a rise in the demand for skilled labor is accompanied by a fall in the demand for unskilled labor. If the hypothesis is to explain why the U.S. earnings distribution has widened while average earnings have remained reasonably stable, then technological change must be predominantly of the extensive sort.

Robotics are the most obvious example of extensive change. Robots, working in conjunction with a limited number of skilled workers, are able displace a much larger number of unskilled workers. Computers used to automate repetitive clerical tasks are another example.

A rapidly proliferating empirical literature has come out in favor of the technological change hypothesis. There is some evidence that firms spending relatively large amounts on R\&D tend to pay relatively high wages to their skilled employees and relatively low wages to

\footnotetext{
${ }^{44}$ See Lawrence (1996).

45 See, for example, Bound and Johnson (1992) and Mincer (1989, 1991).

${ }^{46}$ See Johnson (1997, p. 48).
} 
their unskilled ones. ${ }^{47}$ There is also studies documenting a rise in the wages or wage shares of the people who use computers and a fall in the wages of those who don't. ${ }^{48}$

Recently, Haskel and Slaughter (1998) have argued that changes in earnings inequality can be explained through the sector bias of skill-biased technological change. In particular, they show that the wage differential between skilled and unskilled workers widens when this technological change falls primarily on the skill-intensive sectors. Their empirical work suggests that the changes in these skill premia in various OECD countries over the 1970s and 1980s is closely associated with changes in the sector bias of technological change. But why the sector bias changed remains unclear.

Despite its popularity, the technological change hypothesis remains beset by serious difficulties:

The charge of tautology:

Technological progress, according to the economist's definition, occurs when it is possible to produce more goods and services with the same amount of factor inputs (labor, capital, and raw materials). Thus technological change is commonly measured as the change in national output that cannot be accounted for by the changes in factor inputs. Since technological change is a residual, it will naturally pick up everything that the conventional supply-demand framework has not yet covered. For instance, any movements in the education premium that are not statistically correlated with the other variables under consideration (e.g. changes in the supply of educated versus less-educated labor and movements in the composition of output and the sectoral allocation of physical capital) are attributed by default to the catch-all category of "technological change." The rising earnings of the well-educated people and falling earnings of the less-educated are attributed to "extensive" technological change, defined with the express purpose of accounting for this phenomenon.

In this form, ${ }^{49}$ the technological change hypothesis is unfalsifiable, and thus is not a proper scientific hypothesis at all. In fact, when we say that the rising U.S. inequality is due to "technological change," we come quite close to saying that we don't have a clue about why U.S. inequality has increased.

The only direct evidence on unskilled workers being displaced by skilled ones is in the form of case studies. Although there are investigations of particular industries documenting how production workers give way to skilled operatives,${ }^{50}$ such studies are woefully few in number and cannot be pieced together to yield a comprehensive picture of how skilled and unskilled workers are interacting in the U.S. economy overall.

\section{The direction of causation}

\footnotetext{
${ }^{47}$ For example, Machin (1996) and Machin and Van Reenen (1998).

${ }^{48}$ This is documented in Autor, Katz, and Krueger (1997), Berman, Bound and Griliches (1994), Berndt, Morrison and Rosenblum (1992), Krueger (1993), and Machin (1996).

${ }^{49}$ Of course the hypothesis could be rescued from this charge by a large, comprehensive body of case studies but, as noted, the available evidence is minuscule in comparison to what it required.

${ }^{50}$ For example, Mark (1987).
} 
A closely related difficulty concerns the difference between correlation and causation. The fact that computer use and $R \& D$ expenditures are correlated with earnings differentials across skill groups does not mean that the former caused the latter. ${ }^{51}$ The magnitude of the estimated correlations remains a mystery. For instance, Krueger (1993) claims that computer use on the job can account for $1 / 3$ to $1 / 2$ of the rise in the rate of return to education. Why should computers have had such a strong impact? Such considerations lead one to suspect that computer use might be associated with something else that has a powerful influence on the education wage premium. ${ }^{52}$

\section{The extensiveness of extensive technological change}

It is far from clear why extensive, rather than intensive, technological change should have been so pronounced. Why should so many of the observed technological advances not just have improved the productivity of skilled people, but reduced the productivity of unskilled people by much more? The only heuristic account that delivers this phenomenon is one, as noted, in which the new advances permit skilled people to displace unskilled ones. But many of the low-skill people have jobs that have simply not been amenable to displacement: the large numbers of cleaners, sales personnel, waiters, drivers of vehicles, and social carers are all unlikely to be displaced by a few skilled employees armed with computers.

\section{The influence of technological change on high earnings}

The technological change hypothesis implies that the largest earnings gains fall on the people whose jobs are most heavily reliant on the new technologies. But this does not appear to have happened. Some of the biggest gains have gone to investment bankers, corporate executives, and lawyers, who surely make far less use of computers and the new, flexible, programmable machine tools than engineers, programmers, and computer operatives.

\section{The experience premium}

It is not straightforward to explain the widening of the experience premium through the technological change hypothesis. Other things equal, younger employees are likely to make better use of the new technologies than their older counterparts, since they tend to be more adaptable to new forms of work and since, having received their education more recently, their knowledge is more likely to be in tune with their capital equipment at work. We would expect this influence to compress, rather than expand, the experience premium.

\section{The gender earnings premium}

The technological change hypothesis has great difficulty explaining why the earnings gap between men and women has narrowed in the U.S. and most other OECD countries. Although women are gradually drifting in to many high-wage sectors, they are still concentrated primarily in low-paid sectors such as retailing, wholesaling, catering, hotels and restaurants, social work, and personal services. There is no evidence that these latter sectors benefit disproportionately from the IT revolution and related advances.

Beyond that, the technological change hypothesis doesn't tell us why the new technical advances should be affecting U.S. men and women so differently within the same sectors.

\footnotetext{
${ }^{51}$ See DiNardo and Peschke (1996)

${ }^{52}$ I will suggest below that organizational change may be such a factor.
} 


\section{The international evidence on earnings dispersion}

If technological change was increasing the demand for skilled workers and reducing the demand for unskilled ones in the U.S., we would expect to see similar changes in other countries, particularly within the OECD, since innovations in production processes and product design are generally able cross national boundaries with ease. The international evidence, however, is not favorable. The U.S. and the U.K. are the only OECD countries that have experienced pronounced and persistent increases in earnings dispersion between the mid-1970s and the mid-1990s. Many OECD countries have not experienced increases in earnings inequality in the first half of the 1990s. And where such increases have occurred they appear to be the outcome of significant labor and product market reforms. ${ }^{53}$

Moreover, the U.S. experience of falling real wages for low-wage men has not been widely replicated by other countries with flexible labor markets, such as the U.K. ${ }^{54}$ If extensive technological change is invoked to explain the decline in the bottom of the U.S. male wage distribution, why has this change left many other countries untouched?

U.S. unemployment and the minimum wage:

U.S. unemployment was roughly stable during the 1980s (adjusting for business cycle swings) and fell during the latter part of the 1990s. The major declines in the U.S. minimum wage and unionization rate were most prominent in the 1980s, not the 1990s. In fact, the minimum wage has increased significantly since October 1996, pulling up the wages of Americans in the bottom $20 \%$ of the wage distribution. Under these circumstances, in the context of the conventional supply-demand analysis, nothing short of a rise in the demand for unskilled labor could explain the recent declines in unemployment. Has there been a change in the nature of technological progress that reduced the demand for unskilled labor but increased it in the last two years. If so, where did the change come from?

For these various reasons, I believe the technological change hypothesis is far from telling the full story of what has happened to U.S. inequality.

\section{2d. Wage Rigidities in the Conventional Framework}

Suppose that minimum wage legislation or union activity imposes a wage floor that prevents the unskilled wage from falling sufficiently to equate the supply and demand for unskilled labor. Then the labor market may be pictured as follows:

\footnotetext{
${ }^{53}$ See OECD (1996). For example, Italy's increased earnings dispersion between 1989 and 1993 was probably related to the abolition of scala mobile wage indexation scheme and the abolition of synchronized sectoral wage bargaining.

${ }^{54}$ Although these wages fell in Australia and New Zealand, in Belgium, Canada, Finland, Germany and Japan, they rose by at least as much as the real wages of high-paid men. See OECD (1996, p. 67).
} 


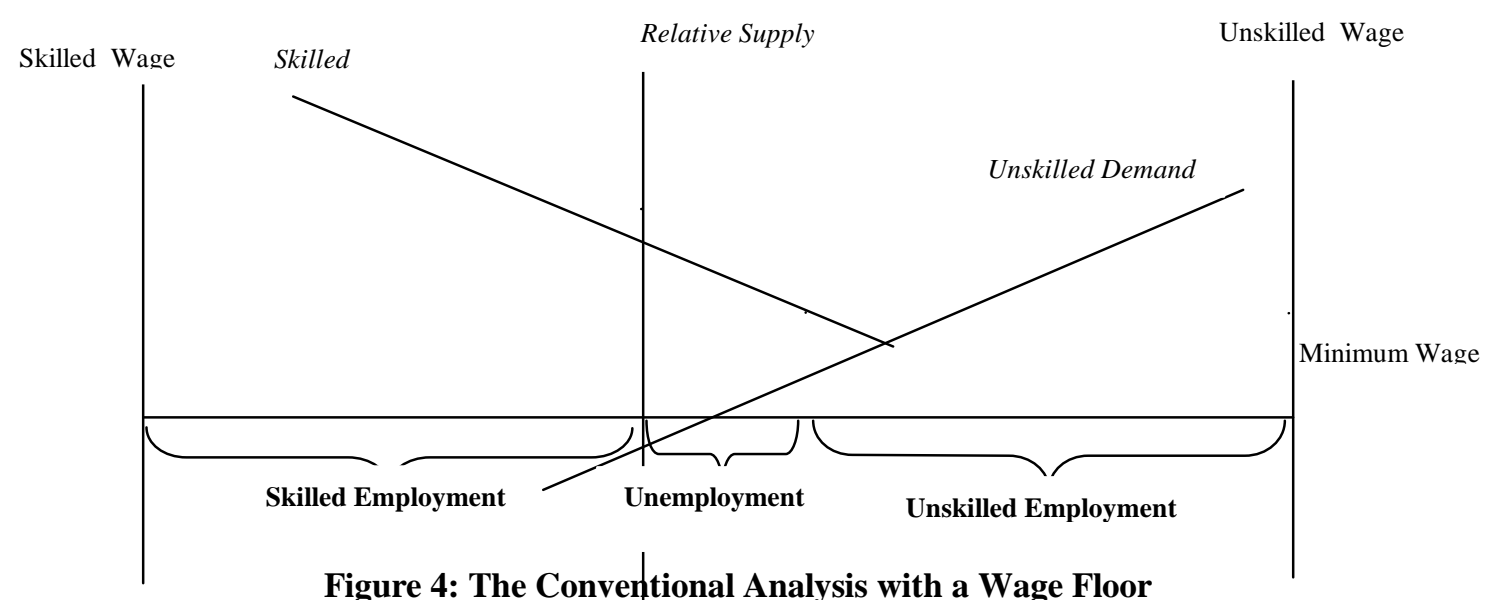

Whereas the skilled wage is given by the intersection of the supply and demand curves for skilled labor, the unskilled wage is determined by the wage floor. The unskilled workers who are unable to find work at the wage floor remain unemployed, as shown.

Consider the effects of an upward shift in the demand for skilled labor and a larger downward shift in the demand for unskilled labor in this context. Had the minimum wage remained unchanged, unemployment would have risen. In order for unemployment to remain stable - a reasonable approximation for the U.S. (adjusting for business cycle swings) - the wage floor must fall. In this way, the analysis suggests that the fall in the U.S. minimum wage must have played a major role in keeping U.S. unemployment low since the 1980s.

The analysis clearly implies that the price of wage compression is unemployment. It also implies that unskilled workers must choose between low wages and high unemployment rates.

\section{Observations that are Harder to Explain Conventionally}

Globalization, deindustrialization, technological change, and wage rigidities are able to account for some prominent stylized facts about inequality but, as we have seen, none of these accounts - whether individually or in combination - is wholly successful. But the difficulties considered thus far are just the tip of the iceberg. We now turn to some empirical regularities that pose tougher challenges to the conventional analysis of inequality.

Fact 6: The Gender Premium: The earnings distributions of males and females in the U.S. have evolved differently over the past 25 years. On average, female earnings have grown much faster than male earnings. For men, the increased earnings dispersion is due more to the losses of the lowest earners than to the gains of the highest earners. Women, on the other hand, have seen gains throughout the earnings distribution, with the highest earners experiencing the fastest earnings growth. 
The gap between male and female earnings has been shrinking gradually since the late 1960s. Between the late 1960s and early 1990s the earnings gap narrowed from $60 \%$ to $40 \% .{ }^{55}$ In part, this development was due to the education premium and experience premium, since the educational attainment of women in the workforce has risen markedly, along with their degree of job attachment. In part, it was due to women's movements into better-paying occupations. But even when education, age, and occupational composition are held constant, the rise of female earnings relative to male earnings remains striking.

Some of the remaining change in the gender premium may be attributed to affirmative action and changes in social norms. But the narrowing of the gender premium has also been significant in countries where such legal and social changes do not appear to have been pronounced.

Before the productivity slow-down of the mid-1970s, the average real earnings of both men and women were growing roughly in line with productivity. Since then, the average real earnings of men have remained flat, whereas those of women have continue to grow at the previous rate. ${ }^{56}$

For men, those in the top $20-25 \%$ of the earnings distribution have experienced positive growth in real earnings growth since the mid-1970s, and the rest have witnessed real earnings declines. Men in the lowest decile of the distribution saw their real earnings decline by over $25 \%$ between 1973 and 1994, while those in the top decile experienced a rise of about $10 \%$ over that period.

For women, like for men, people's position in the earnings distribution was correlated with their earnings growth; but whereas most men have experienced earnings declines over the past two decades, most women have witnessed earnings growth. Women in the lowest decile saw their earnings rise by about $4 \%$, while those in the highest decile experienced a rise of over 35\% between 1973 and 1994.

Since women earn less than men, it has frequently been suggested that the fall in the gender wage premium was due increased competition between women and men in the labor market. According to this account, as women entered the labor force in ever greater numbers

\footnotetext{
${ }^{55}$ See Gottschalk (1997).

${ }^{56}$ Men's average real weekly earnings grew at 2.9\% per annum between 1963 and 1973, but no trend since then. Women's average real weekly earnings grew at $2.8 \%$ per annum between 1963 and 1973, and at 2.7\% per annum from 1973 to 1993.
} 
and competed more vigorously with the low-paid men, the wages of these men were driven down further.

The problem with this story is that the increasing supply of working women can reduce the wages of low-wage men only if the two groups are substitutes for one another. But if they are, it is a mystery why the wages of women have risen while those of the low-wage men, for whom the women substitute, have declined. On the other hand, it is far from clear that the women and men are good substitutes for one another, since the women have tended to enter different occupations and industries than the ones where the low-wage men are concentrated.

Another problem with this account is that the historically large increase in female labor force participation occurred in the 1970s, whereas the large fall in the wages of lowwage men occurred mainly in the 1980 s.

Fact 7: The Trade-off between Low Earnings and High Unemployment: Comparing OECD countries over the past 25 years, there is no clear trade-off between wage dispersion and unemployment.

At first glance this statement sounds surprising, since it appears to contradict a popular macroeconomic theme, namely, that the European unemployment problem is the flip side of the U.S. problem of the "working poor." It is certainly true that, over the 1980s and 1990s, the EC countries (with the exception of the U.K.) have experienced little increase in earnings dispersion, but a strong and persistent climb in the unemployment rate. And over the same period the U.S. witnessed a strong and persistent climb in earnings dispersion at a roughly constant unemployment rate. Moreover, the people whose earnings are relatively low in the U.S. - the less-educated and the young - are the ones whose unemployment rates are particularly high in continental Europe. And the 25-year period during which the wages of unskilled workers fell in the U.S. corresponds roughly to the period when unemployment rates of these workers rose in much of continental Europe.

This picture looks compelling and seems to fit perfectly into in the conventional framework, where a rise in the wage floor reduces wage inequality but increases unemployment. However, the apparent trade-off between earnings dispersion and unemployment disappears when OECD countries are examined individually.

By various measures, the U.S. and Canada have had particularly wide earnings dispersion since the mid-1980s; Australia, Sweden, and the U.K. fall into an intermediate 
range; and Germany and the Netherlands have a relatively equal distribution of earnings. ${ }^{57}$ But there is no inverse relation between these rankings and unemployment rankings. Canada (with high earnings dispersion) has had an unemployment rate that is roughly double that of the Netherlands (with low earnings dispersion.) ${ }^{58}$ Although Germany and the Netherlands are relatively egalitarian, Germany's unemployment rate is well above that of the Netherlands (even after allowance has been made for the special circumstances of East Germany).

Furthermore, the wage-floor rationale for the earnings-unemployment trade-off runs into trouble in some OECD countries - notably Canada, Finland and Germany - which have experienced declines in earnings dispersion between the mid-1980s and mid-1990s without appreciable increases in either minimum wages or union density.

Finally, if the supply-demand framework told the whole story, then we would expect the unemployment rates of the poorly educated people (who tend to be low earners) to be much lower in the high-inequality countries (such as the U.S. and the U.K.) where wages are allowed to fall than the low-inequality countries (such as Germany and France) where wages are propped up through minimum wage laws and welfare entitlements. But this turns out not to be true. The unemployment rates of the poorly educated people are roughly the same across these countries. ${ }^{59}$

Fact 8: The Skill Incidence of Unemployment: In OECD countries since the 1970s, rising unemployment has not fallen exclusively on the low-paid, unskilled workers. There have been some appreciable increases in skilled unemployment as well.

The globalization, deindustrialization, and technological change hypotheses imply that the rising unemployment experienced in the EC and some other OECD countries must have fallen on unskilled people. But skilled people have felt the crunch as well.

In countries that experienced a substantial increase in unemployment rates over the 1970s and at least the first part of the 1980s - such as Canada, Germany, the Netherlands, Spain and the UK - a significant proportion of the rising unemployment rates fell not only on the unskilled, but on the skilled as well. By contrast, unemployment was concentrated primarily on the unskilled in countries that had comparatively low unemployment rates over that period - Japan, Norway, Sweden, and the U.S.

\footnotetext{
${ }^{57}$ See Gottschalk and Smeeding (1997).

${ }^{58}$ In May 1998, the unemployment rate in Canada was $8.4 \%$, while in the Netherlands it was $4.3 \%$.

${ }^{59}$ See Phelps and Zoega (1996).
} 
The recession of the early 1990s was even more paradoxical in this respect, since the unemployment increases then fell even more heavily on the well-paid, skilled labor. Of the countries above, only Japan experienced no substantial rise in skilled unemployment. ${ }^{60}$

But while skilled unemployment is not invariably a negligible phenomenon, it is important to keep in mind that unskilled unemployment tends to be twice to three times as high as skilled unemployment in OECD countries. Thus a percentage change in the unemployment rate of unskilled people corresponds to a much greater change in the numbers unemployed than an equal percentage change in the unemployment rate of skilled people.

Fact 9: Earnings Instability: Over the 1980s in the U.S., the overall increase in earnings dispersion was due as much to earnings instability as to permanent changes in earnings inequality.

Greater variability of transitory earnings played just as important a role as greater dispersion of permanent earnings, on both a weekly and annual basis. The globalization, deindustrialization, and technological change hypotheses are primarily rationales for increased inequality in permanent earnings. It has been claimed that technological change and increased competition due to international trade may have increased the volatility of firms' revenues and thereby also the volatility of their employees' marginal revenue products, but these implications remain largely unexplored.

It is of course true that when earnings dispersion increases, then a given amount of mobility between jobs will on average lead to a greater degree of earnings instability. ${ }^{61}$ But there is evidence that earnings instability affected not only those who switched jobs, but also those who remained at the same job. ${ }^{62}$ This is also the reason why a decline in job duration cannot provide a full account of earnings instability. The rise in the variability of weeks worked can also give only a partial account, since weekly earnings became less stable as well. Besides, declines in job duration and increases in the variability of weeks worked are not straightforwardly explicable in terms of the globalization, deindustrialization, and technological change hypotheses.

The fall in unionization over the 1980s may well have played a role, but transitory earnings became less stable not only among unionized workers, but among non-unionized ones as well.

\footnotetext{
${ }^{60}$ See Nickell and Bell $(1995,1996)$.

${ }_{62}^{61}$ am grateful to Kevin Murphy for this point.

${ }^{62}$ See Gottschalk and Smeeding (1997, p.651).
} 
Fact 10: Within-Group Inequality: In the U.S., at least half of the rise in earnings inequality occurred within groups, defined by observable traits such as education, experience, occupation, race, and gender.

U.S. earnings dispersion has risen not just because people with different (easily observable) characteristics have received different rewards for their work but, equally important, because people with the same set of such characteristics have also been rewarded unequally. The issue, for example, is not just that the earnings of well-educated people have risen faster than those of less-educated people, but also that the earnings of people within any particular educational group have fanned out as well.

This phenomenon poses a severe problem for the globalization, deindustrialization, and technological change hypotheses since they are primarily rationales for changes in "between-group" inequality.

Some "within-group" inequality is related to earnings instability, for as people's earnings become more unstable, the transitory earnings of people within any particular group become more variable. It has been estimated that about a third of the rise of "within-group" inequality is due to the greater volatility of earnings. ${ }^{63}$ That leaves a lot of the increased "within-group" inequality to be explained.

It is of course possible to argue that each group - based on education, experience, occupation, race or gender - is composed of individuals with different unobservable characteristics and that these characteristics have received differential rewards. ${ }^{64}$ Why this should have happened remains unexplained thus far. And obviously, since unobservable characteristics are unobservable, the evidence in favor of this approach is inherently circumstantial.

\section{The Organizational Revolution}

The discussion thus far indicates that while the conventional supply-demand framework is informative, many important features of inequality in the capitalist world are not captured adequately. To gain significant further insight, in my judgment, we need to look further afield. The aim of this section is to consider some new ideas and the discussion of them will necessarily be conjectural.

\footnotetext{
${ }^{63}$ See Gottschalk and Moffitt (1994).

${ }^{64}$ See, for example, Murnane, Willet and Levy (1995)
} 
One momentous phenomenon that is missing from the conventional account is organization change. ${ }^{65}$ There is good reason to believe that the advanced industrialized countries are beginning to witness an Organizational Revolution whose economic, social, and political implications are as far-reaching as those of the Industrial Revolution. ${ }^{66}$ The critical elements of the current transformation are changes in the organization of production, of work, of product design, of marketing, and of authority within business enterprises. These organizational changes are all interdependent and mutually reinforcing. Over the past decade they have received a lot of attention in the news media and they are a hot topic in the business management literature as well as in sociological research, ${ }^{67}$ but they have gone largely unnoticed in the mainstream economic literature thus far. Like the Industrial Revolution, the Organizational Revolution has powerful implications for the changing patterns of inequality.

Let's begin by noting that the Organizational Revolution is not exclusively about organizational change, just as the Industrial Revolution wasn't exclusively about industrial change. The Industrial Revolution was a multi-faceted phenomenon, characterized by an unprecedented, explosive increase in industrial output, an avalanche of technological change (particularly of manufacturing inventions), rapid expansions of international trade, vast increases in agricultural productivity, and accelerated population growth.

The Organizational Revolution is multi-faceted as well, also involving technological change, international trade, and a host of other phenomena, surveyed below. But, by the nature of the new innovations and skills, organizational change appears to be playing a particularly significant role this time round.

The Industrial Revolution was driven, to a significant degree, by inventions that permitted mass production through the exploitation of economies of scale. Coke-smelting of iron, the steam engine, the weavers' flying shuttle, the spinning jenny, steel-making through puddling, the agricultural threshing machine, the railway, and other breakthroughs all promoted this development. In the main, that is what was "industrial" about the Industrial

\footnotetext{
${ }^{65}$ Many of the ideas in this section are the outgrowth of my collaborative work with Assar Lindbeck. In particular, see Lindbeck and Snower (1995, 1996a,b, 1997).

${ }^{66}$ The term "Industrial Revolution" is used loosely here to refer to both the First and Second Industrial Revolutions, covering a period from the mid- $18^{\text {th }}$ century to the late $1960 \mathrm{~s}$.

${ }^{67}$ Some examples of business studies describing the broad contours of the organizational changes are Hammer and Champy (1993), Cowen and Parker (1997), NUTEK (1996), Pfeiffer (1994), and Wikström and Norman (1994). Various isolated aspects of these changes have been considered in the economic literature, e.g. Appelbaum and Bott (1994), Kremer and Maskin (1995), Lindbeck and Snower (1995, 1996a,b, 1997) Milgrom and Robers (1990), Mitchell, Lewin and Lowler (1990), Levine and Tyson (1990), and Piore and Sabel (1984).
} 
Revolution. By contrast, the Organizational Revolution is propelled, in large part, through advances in computer and telecommunication technologies in conjunction with corresponding human skills, transforming the flow of information in modern economies. A major implication of this transformation is that it calls for new forms of organizing economic activity and these, in turn, appear to be exerting a major influence on the recently evolving patterns inequality. ${ }^{68}$

\section{4a. Driving Forces behind the Organizational Revolution}

The Organizational Revolution appears to be driven by at least four major economic forces, occurring in seemingly unrelated, but nevertheless highly inter-dependent, areas of economic activity:

1. Changes in physical capital: The major technological advances in the Industrial Revolution permitted the production of standardized outputs through standardized inputs. In part, this became possible through large, specialized manufacturing equipment, capable of turning out large quantities of goods, and through the invention of machines with sufficient durability and accuracy for the manufacture of interchangeable parts. This physical capital required large production runs to exploit economies of scale. Since the machines performed single-purpose, repetitive tasks, the workers who manned them were required to engage in single-purpose repetitive tasks as well.

The recent changes in physical capital are quite different in nature. They include multi-purpose machine tools; programmable manufacturing equipment; computer-aided design (CAD), computer-aided manufacturing (CAM), and computer-integrated manufacturing (CIM) - all of which permit "mass customization" of highly differentiated products through capital inputs that are highly flexible and versatile. The new physical capital permits relatively small production runs, since economies of scale have been radically reduced through the introduction of computerized, multi-purpose machines that are easy to switch between different production tasks. The new machines also facilitate increasing integration between design, production and marketing. As the machines have

\footnotetext{
${ }^{68}$ It could of course be argued that organizational change is a form of technological change and thus the purported Organizational Revolution is just a variant of the technological change hypothesis. This is a semantic point, but an unhelpful one. Technological change does not always involve momentous organizational change; it is often argued that the rapid growth in advanced market economies during the first 25 years of the postwar period was fuelled by technological progress but not much change in organizational forms, which continued to
} 
become more versatile, the workers who man them are required to be more versatile as well.

2. Changes in information technologies: The recent advances in IT have transformed the flows of information between managers and front-line workers, between firms and their suppliers, and producers and consumers. In many firms nowadays, managers and workers have access to timely information about design problems, production bottlenecks, order backlogs, availability of input supplies, customer requests, inventories, cash flow difficulties, and many other aspects of their business activities.

3. Changes in human capital: The education and training systems of advanced industrialized countries have generated a steadily increasing supply of skilled workers. Not only are the these workers capable of performing particular occupational roles more effectively than in the past but, more significantly, they are also able to perform ever wider ranges of tasks. In other words, to be well-educated nowadays does not merely mean a higher degree of specialization within a particular discipline, but also a greater span of competence. Thus human capital, like physical capital, has become more productive in the supply of particular outputs and also more versatile.

4. Changes in the preferences of employees and consumers: As people have acquired more versatile human capital, their work preferences have changed. The old-style, fragmented, repetitive jobs now seem increasingly onerous, and educated employees are demanding more varied work that allows them to exercise their multiple skills, along with initiative, creativity, and judgment. Furthermore, as human capital has grown - along with productivity and living standards - consumers in the advanced industrialized countries have come to attach increasing value to product variety and customization.

These driving forces all reinforce one another and call for new organizational structures. Once again, it is instructive to compare the developments now with those associated with past industrialization.

\section{4b. The Division of Labor}

The Industrial Revolution generated technological changes that permitted vast increases in productivity, provided that the organization of work, production, marketing, and 
economic authority was radically restructured. The key element of this restructuring process was the division of labor.

In order for workers to interact effectively with the large, single-purpose machines that were being created, work needed to be divided into highly fragmented tasks. The assembly line is an advanced manifestation of this process. The division of labor in production reduced the need for training, since it was not necessary to have long spells of education or prolonged job experience to do a small number of precisely defined tasks.

However, as work became more and more fragmented across production tasks, the process of coordinating these tasks became more and more difficult. Economies of scale in production came at the expense of diseconomies in management. To overcome this problem, the division of labor was applied to the managerial process itself. The result was the organization of large firms into functional departments, such as design, production, marketing, finance, and administration departments. The fragmentation of production and managerial tasks called for a thorough-going centralization of decision making within firms. On this account, it was necessary to create managerial pyramids, in which senior executives communicated with the functional departments via layers of middle management. The middle managers were the conduit for the flow of information within the firms: information about strategic decisions from the senior executives to the rank and file, and information about market conditions, production problems, financial constraints, etc. from the rank and file to the senior executives.

The division of labor in production and management was the organizational foundation of the Industrial Revolution.

More recently, since the 1970s, it appears that we are witnessing the beginning of another revolution which, once again, permits vast increases in productivity, provided that the organization of economic activity is restructured along entirely new lines. Under the influence of the recent advances in physical capital, standardization of products is increasingly giving way to customization. Through the advances in information technologies, centralization of decision making in the hands of senior executives is no longer essential to ensure coordination and consistency in business activity. Instead, sophisticated computer systems allow the rank and file to communicate with each other and exchange detailed information that would be impractical for middle management to transmit. The division of labor into fragmented tasks is frequently being reversed, as workers use the new information 
technologies in combination with their multiple skills to perform multiple tasks and rotate among jobs that were previously allocated to different occupations.

The organizational framework that we have inherited from the Industrial Revolution including the functional departments within firms, the occupational divisions among workers, the managerial hierarchies - is simply not appropriate to the new economic opportunities that have arisen. In particular, it does not enable us to take advantage of the recent changes in physical capital and information technologies, to make use of people's broader ranges of skills, or to satisfy employees' demands for more varied work and consumers' demand for more highly differentiated products. It is impossible to reap the new productivity gains through incremental changes to pre-existing organizational structures - for the same reason that it was impossible to reap the productivity improvements from steam engines, railways, and assembly lines through craftsmen and apprentices. What is needed is a fundamental transformation of the organizational structures themselves. This, in my judgment, is the process we are witnessing nowadays, and the changing patterns of income inequality are symptoms of this process.

\section{4c. Illustrative Examples}

The only way to get a feel for what is going on is to consider some specific cases of the new-style organizational change. While the following are just a few illustrative examples, there is a vast array of consonant case studies in the business administration literature. ${ }^{69}$

Product development at Kodak: Up until the late 1980s, Kodak designed its cameras through a parallel process (i.e. the different parts of the cameras were designed at the same time and integrated afterwards) and put together its manufacturing tooling later on. This organizational scheme was too slow to allow Kodak to maintain its market share. Consequently Kodak reorganized its product development through "concurrent engineering," involving CAD/CAM. Thereby the various teams of design engineers use an integrated database, which they share with the manufacturing engineers. The new physical capital and information technologies permit product designs to be used directly in the manufacturing process. Furthermore, it is no longer necessary for design and manufacturing to be sequential processes; on account of the computerized interaction between the designing and the manufacturing employees, the latter can get to work well before the former are finished. Since the designers and manufacturers now need to communicate their ideas to one another, their range of tasks has expanded. As result, Kodak's product development process has speeded up considerably.

IBM Credit: This subsidiary of IBM, which provides financing to the buyers of IBM's goods and services, took an average of six days to process a financing request. In this period some potential customers were lured to IBM's competitors. The reason for the long processing time was a minute division of labor: the salespeople contacted clerks who logged the financing requests, which were turned over to the credit department to check for creditworthiness, whereupon the business practices department drew up loan agreements, which then went to pricers who determined the appropriate interest rates, who handed the information to clerks who drew up a letter to the salesperson. Eventually, IBM Credit reorganized its activities along radically new lines. It replaced most of its specialized administrators by "deal structurers," who performed all the steps in the financing process in

\footnotetext{
${ }^{69}$ The first four examples are taken from Hammer and Champy (1993) and the next two from Wikström and Norman (1994).
} 
conjunction with a newly installed computer system, containing all the relevant information. From then on, only the anomalous cases were sent to a small team of specialists. As result, the turnaround time for financing requests shrank, on average, from six days to four hours.

Bell Atlantic: In setting up high-speed, digital circuits for its business customers, Bell Atlantic suffered from delays and coordination problems when forms were passed from department to department. But unlike IBM Credit, it was unable to replace its specialists by generalists, since the operation was far too complex to be handled by a single individual. Thus Bell Atlantic divided the relevant workforce into teams, each of which had complete responsibility for installing the equipment. The members of teams were no longer able to restrict their work to their previously defined, narrow occupational descriptions, for they now needed to communicate and cooperate with one another, acquiring a portfolio of new skills and an awareness of what other team members are doing. Consequently, Bell Atlantic reduced installation time from 30 days to 3, while reducing supervision and administration costs.

Hallmark: In the 1980s Hallmark, the dominant firm in the U.S. greeting card industry, observed that its customers were becoming more heterogeneous and its retailers, facing higher shop rents, were requiring quicker product turnover. Consequently, Hallmark found its product lines rising, its print runs falling and its costs per unit of output growing ominously. Moreover, as size of its various market segments shrank, it became increasingly difficult to forecast sales, increasing the risk of being left with inventories of inappropriate greeting cards. Thus in 1989 the company began to restructure, installing point-of-sale computer systems that used barcodes to track information on each card purchase and introducing computerized decision-support systems that enabled the Hallmark executives to make convenient use of this information. Furthermore, employees were grouped into teams, each responsible for a particular product. The computer systems made it easier to predict sales and adjust print runs accordingly; the creation of teams eliminated a lot of paperwork, radically shortened decision lags (as orders no longer languished in people's in-trays), and reduced for managerial reviews of interim products.

Volvo's laundry: Volvo purchased its laundry services from a large supplier, who performed the job in the traditional way, which was expensive, slow, and error-prone, since it required frequent communication by phone and fax to establish Volvo's needs. Eventually, Volvo and the laundry jointly transformed the operation into a clothing management business, in which the "laundry" not only cleaned occupational clothing, but also altered it to fit people of different size and recommended style changes to avoid injury and reduce wear and tear. As the laundry changed its job description, the need for communication between the purchaser and provider rose markedly. This need was met through an expressly installed computerized system. In order for the organizational transformation to succeed, employees in both the purchasing and providing firms needed to relinquish their prior notions of what buying and selling laundry services involved.

McKesson: In the 1970s McKesson, an American wholesaler of pharmaceutical products, found that its customers - independent, specialist retailers, such as local drug stores - were losing market share. Consequently, McKesson restructured its operations, ceasing to be solely a pharmaceutical supplier and becoming a management consultant as well. McKesson offered its retailers management training and advice on store layout. It also helped its retailers install computer systems that speeded up the ordering process and helped identify customer needs and offer more individualized service. To ensure the success of the restructuring process, the employees in McKesson and its retailers had to abandon their previous division of tasks and expand their occupational pursuits. The transformation brought McKesson into close association with its customers and, by enhancing their market share, increased the volume and reduced the volatility of McKesson's sales.

My local garage: When my car started sputtering over a decade ago, I drove it to my garage, where I related the problem to a customer representative, who wrote my complaint onto a form. The form was then put into the intray of a mechanic. The mechanic fixed cars in the order in which the associated forms appeared in his in-tray. It was virtually impossible to predict when my car would be seen, since no one new how long it would take to fix the cars in line ahead of mine. When the mechanic was finished with my car, he would fill in a new form, which was sent to the accounts department, which would prepare my bill. I then drove the car round the block, found that it was still sputtering, and returned it to the customer representative for another iteration. When a similar problem arose several weeks ago, however, I was told to explain my problem personally to one of a new team of mechanics who happened to be free. He typed the information into a computer and started working while questioning me about the problem. When he was done, he pressed a button on his keyboard, and a printer 
printed out my bill. We tested the car together, in which time he tried to sell me a new car. Unlike his predecessor a decade ago, the new-style mechanic required skills that went well beyond fixing a car.

These and the many other documented experiences illustrate the vastly diverse manifestations of the Organizational Revolution. Although the driving forces have a common thread - new information technologies; flexible, computerized physical capital; the intensive use of versatility in the exercise of skills, combined with the ability to communicate and exercise judgment; and the demand for greater product diversity - the resulting organizational transformations are very varied indeed. Nevertheless, there are some salient features that recur with uncanny frequency.

\section{4d. Consequences of the Organizational Revolution}

The following features have potentially important implications for inequality:

- Transformed organization of authority within firms: The pyramid structure of the command-and-control style of management - in which authority flows from the senior management, down through middle management, to the rank and file in functional departments - is being replaced by a much flatter, more rectangular organizational structure. Whereas the old-style, "Tayloristic" companies divided along broadly occupational lines, with different departments performing different tasks, the new, "holistic" companies tend to be organized around customer-oriented teams. The switch from task-orientation to customer-orientation has meant that the new teams can report to senior management with few, if any, intermediaries. This helps explain the often observed "delayering" of middle management. The members of the new customer-oriented teams often require a broader range of skills, an ability to cover for one another that comes with some job rotation, and a facility to communicate and cooperate effectively with one another.

- Transformed organization of design, production, and marketing: The introduction of computerized data systems, flexible machine tools, and programmable equipment frequently means that product design, manufacturing, and marketing no longer need to be performed sequentially and largely independently of one another. In fact, it has become economically desirable for these areas to interact with one another - enabling designers to become promptly aware of changing consumer preferences, production workers to inform designers of manufacturing problems, and marketing experts to be informed quickly of 
new product developments. In the process, employees are frequently required to concentrate less on how well they perform particular occupational functions and more on how their efforts - regardless of job description - promote customer satisfaction. This organizational change often calls for the exercise of initiative, creativity, and social competence. Techniques such as "lean production" and "just-in-time production" are not just ways of reducing inventory storage costs. Rather, they are primarily devices for exposing production flaws and bottlenecks where they arise, and thereby decentralizing the authority for overcoming them.

- Transformed organization of purchaser-provider relationships: Many purchasers are beginning to play a much more active role in the design of the goods and services they buy. Volvo's interaction with its laundry service supplier and McKesson's ongoing dialogue with its retailers are good examples. IKEA, one of the world's largest furniture companies, does much of its business by providing a wide variety of furniture components, which its customers assemble to suit their idiosyncratic specifications. Customers are ceasing to be passive recipients of products and are increasingly becoming participants in the production process. As the distinction between "production" and "consumption" becomes blurred, companies often face a growing need for employees with good communication skills, regardless of what else their primary jobs may involve. ${ }^{70}$

- The breakdown of occupational barriers: As employees are given multiple responsibilities, spanning multiple tasks, the distinctions between different occupations often become fuzzy. The reorganization of IBM Credit, Bell Atlantic, and Hallmark are instances of how employees may be required to take on wider ranges of complementary tasks, which were previously divided among separately functioning units of their firms. What appears to matter a lot in the new, holistic organizations is not just competence at a particular task, but the potential to acquire multiple skills and the ability to use the skill acquired at one task to enhance one's productivity at another task. Beyond that, technical abilities often need to be complemented by social skills, self-motivation, and selfassessment.

\footnotetext{
${ }^{70}$ Note, however, that closer information links between customers and sellers does not necessarily imply greater need for interpersonal communication. For example, Beneton uses its computerized information on day-to-day sales to adjust its computerized, robotic production of individual products and to ship these products to the appropriate sales outlets. (See Wikström and Norman (1994).)
} 
Although there are many variations to these trends, ${ }^{71}$ the broad tapestry of case studies in the business literature suggest that the phenomena above are widespread. It is however inherently difficult to quantify these developments and data has not been collected on a sufficiently broad and comprehensive basis thus far to permit thorough-going statistically analysis. In this sense, the evaluation of organizational change is subject to the same limitations as the evaluation of the technological change hypothesis - for both, direct evidence resides in a limited number of case studies (although the studies on organizational change appear to be far more plentiful). With these cautionary concerns in mind, let us consider what the phenomena above might imply for inequality.

\section{4e. The Influence of Organizational Change on Earnings Inequality}

It is tempting to view "organizational change" as just another potential factor alongside technological change, globalization, and deindustrialization - that causes the demand for skilled labor to shift relative to the demand for unskilled labor. According to this line of thinking, we simply need to determine how organizational change affects these relative demands, and then the competitive supply-demand framework can be used to infer the resulting changes in earnings differentials by skill. But this temptation should be resisted. The organizational change discussed above does not just influence firms' needs for particular skills; it redefines the required skills.

Since the Organizational Revolution is changing our conception of "skills," it makes little sense to say that the demand for "skilled labor" has increased at the expense of "unskilled labor," because the skills appropriate to the traditional organizational structures are different from those appropriate to the new ones. Such transformations have occurred repeatedly in the past. Prior to Industrial Revolution, craft production relied exclusively on handicraft skills: craftsmen used hand tools to make customized products. Being skilled in this domain meant having the ability to perform a wide variety of related tasks necessary for the production of entire products, from start to finish. It often also involved the ability to train apprentices and work within small teams. But once the Industrial Revolution was in full swing, being skilled meant, among other things, the ability to operate, maintain, and work in

\footnotetext{
${ }^{71}$ For instance, many companies in the advanced, industrialized countries "outsource" part of their manufacturing process to low-wage, developing countries where work is performed along the strictly traditional, Taylorist lines. This phenomenon makes sense, since the developing countries often lack the new physical capital, the information systems, and the versatile, well-educated human capital needed to take advantage of the organizational changes outlined above. To some degree, therefore, the traditional organization of production and work is shifting geographically rather than being replaced by new organizational forms.
} 
conjunction with the newly invented machines, to supervise workers in the newly erected factories, and to manage the flow of mass-produced goods to mass markets.

Now the Organizational Revolution is again redefining what we mean by skills. To be "skilled" in the new organizational setting often means, as noted, versatility across tasks, the ability to learn new tasks, the aptitude to take advantage of complementarities between them, and the ability to communicate with other employees in a team, with suppliers, and with customers. It may involve the ability to accept some responsibility and decision-making power within teams and to take initiative in responding to changing customer needs.

In short, the Organizational Revolution is increasing the demand for a new set of labor characteristics. Other things being equal, people who have the desired characteristics are seeing their earnings rise at the expense of people who don't have these characteristics. This reasoning can help us account for some of the observed empirical regularities but, as we shall see, it probably does not go nearly far enough.

We first consider the Organizational Revolution's possible implications for inequality that are traceable within the conventional supply-demand framework under perfect competition and perfect information, and we then turn to implications that require us to look beyond this framework.

\section{Rising Earnings Dispersion}

The Organization Revolution can help explain why the dispersion of U.S. earnings was reasonably stable between the early 1950s and the mid-1970s, but widened markedly since then. Although the period between the early 1950s and mid-1970s was a time of rapid growth, there is ample evidence that it did not involve much organizational change. For the most part, firms were exploiting technologies of mass production and mass marketing, along with managerial structures, that had been developed as early as the 1920s. ${ }^{72}$ Thus the "golden years" of the early postwar era were a time of consolidation. The rapid dissemination of computer and related production technologies - in manufacturing equipment, PCs, business data systems, and elsewhere - began in the mid-1970s. Now, over two decades later, we are still just beginning to learn how to exploit the true potential of these technologies through the appropriate reorganization of economic activities. Just like the early postwar period thrived on the exploitation of well-known complementarities - such as those between road networks,

\footnotetext{
${ }^{72}$ See, for example, Drucker (1969)
} 
suburban development, automobiles, and the exploration, development, and transport of oil so the current era is devoted to reaping the benefits from a new set of technological and organizational complementarities. This involves reorganizing economic activities to take advantage of the new advances in physical and human capital and to satisfy people's growing need for stimulation and variety in the jobs they perform and the goods and services they consume. In the process, some labor characteristics - versatility, initiative, communication skills, and so on - come to be highly prized, and workers with these characteristics see their earnings rise. The abilities of other workers - frequently those of single-skill, blue collar males - cease to be appropriate to the new technical and organizational environment, and they see their earnings fall.

\section{The Rising Education Wage Premium}

The Organization Revolution can also help shed new light on why the U.S. education wage premium has increased since the 1980s. In addition to being relatively productive at particular skills, well-educated people are likely to be relatively versatile across skills. This conjunction between versatility and productivity can have powerful implications for inequality. To make them transparent, consider the following thought experiment. Suppose that the feasible range of skills could be ordered along a line, from lowest to highest, where a "high" skill commands higher wages than a "low" skill. Furthermore, suppose that in the traditional organization of work, each employee exercises just one skill - viz. the highest skill at his or her disposal - and the more education the employee has received, the higher the corresponding skill. In this context, there is a one-to-one correspondence between the distribution of skills and the distribution of wages by educational attainment.

Next, suppose that work is reorganized so as to permit the exercise of multiple skills. The well-educated workers now not only have access to higher skills, but also to a broader range of interrelated skills, than their less-educated counterparts. Thus the well-educated workers proceed to exploit complementarities among a variety of high skills, and consequently their productivity and wages turn out to be much higher than had they exercised any of these skills individually. The less-educated workers, by contrast, are left with a narrow range of low skills, so that their productivity and earnings fall far behind that of the welleducated colleagues. In fact, as the organization of work is transformed in favor of multiple 
skills, the less educated workers may actually see their productivity and earnings fall in absolute terms.

Although this thought experiment is extremely simplistic, it is useful in highlighting how recent organizational changes could have amplified the education premium well beyond the effect of education on productivity at any particular skill.

\section{The Decline of Centralized Bargaining}

Recent organizational changes can also provide an explanation for the rise in decentralized wage bargaining in many OECD countries. Numerous case studies have suggested that changes in the organization of work have been crucial in promoting the decline of centralized bargaining. ${ }^{73}$ What centralized bargaining agreements have in common is that they strive for "equal pay for equal work," which means paying different people the same amounts for performance of the same tasks. While this practice may not be very inefficient when different employees do different tasks, it can become extremely inefficient when work is reorganized to promote the performance of multiple, complementary tasks. ${ }^{74}$

The problem arises when different employees perform different sets of complementary tasks - something that is quite likely to occur in the customer-oriented teams of modern firms, and even more likely to manifest itself across firms producing highly differentiated products for highly idiosyncratic consumer markets. Under these circumstances, the productivity of an employee at a particular task may be quite different from that of another employee at the same task, because the two employees perform that task in conjunction with different sets of other tasks. For example, the productivity of dealing with customer complaints may be quite different for an employee who is also engaged in product design than for one who is also on the production line. Consequently employers will want to offer different workers different remuneration for the same task, depending on what other tasks they do. But this is precisely the practice that centralized bargaining inhibits. So, as firms restructure, centralized bargaining may be expected to become increasingly wasteful, and consequently employers and employees alike are likely to become increasingly resistant to it.

Beyond that, the Organizational Revolution suggests rationales for observations, discussed above, that are hard to explain by the conventional analysis.

\footnotetext{
${ }^{73}$ See, for example, Katz (1993), Locke (1992), Mathews (1989), Thelen (1991), and Turner (1991).
} 


\section{The Gender Wage Premium}

For a wide variety of reasons, women are often more willing and able to embrace work that is flexible in terms of hours, intensive in social skills, and versatile in terms of tasks. First, mothers on average spend more time caring for their children than fathers, and thus mothers have a greater demand for jobs with flexible hours. Even women without children tend to demand greater time flexibility, in part because they spend more of their time caring for relatives and friends. Second, women tend to be attracted to jobs requiring a relatively high degree of interpersonal contact. Retailing, school teaching, nursing are examples. Third, there is some psychological and sociological evidence that, on average, women tend to be more receptive to multi-tasking and job rotation than men, particularly the unskilled men. The reasons for this remain unclear. It could be education, since men tend to specialize in narrower fields than women. Or it could be custom and tradition: women's jobs in the home often involve a wider range of tasks than men's pursuits within rigid occupational lines. Or it could be a technological phenomenon: the jobs that are intensive in communication and other social interaction - jobs that attract a disproportionate share of women - often tend to involve a relatively wide range of tasks.

These traits - temporal flexibility, interpersonal skills, multi-tasking - are precisely the ones that the Organizational Revolution appears to favor. On this account, women's productivities and earnings may be expected to rise relative to those of men.

\section{The Rise of Earnings Instability}

As noted, the newly structured businesses are designed to respond more quickly to changing customer needs. Advances in information technologies have reduced product development lags, flexible production equipment has permitted production in smaller batch sizes, and the integration of design and manufacture has allowed production to respond more readily to preference swings. To give employees incentives to expedite this process, remuneration schemes have become more flexible, with less attention given to competence at predefined tasks and greater emphasis placed on revenues and customer satisfaction. Under these circumstances, earnings should may be expected to become more volatile.

\section{Within-Group Inequality}

\footnotetext{
${ }^{74}$ Lindbeck and Snower (1996b) provide a formal analysis of this problem.
} 
When workers' tasks are defined by the rigid operation of single-purpose machines, when these tasks are simple and repetitive, and when little training is needed to perform them, it is not surprising that different workers' performance at any particular task should turn out to be quite homogeneous. But when workers, interacting with more flexible machines and computerized equipment, are given discretion to perform different sets of complementary tasks, their performance tends to become more idiosyncratic. When the need for social competence, initiative and judgment at the new types of jobs is taken into account, employees' dispersion of productivities is likely to increase even more. Needless to say, people differ enormously in their versatility across tasks and their personal interaction skills. But whereas previous technologies and organizational structures hid these differences by forcing people to work within procrustean job slots, the new economic environment allows these differences to manifest themselves in job performance. Consequently, inequality may be expected to rise within any particular education, experience, or gender group.

\section{4f. Efficiency Wages and the Insider-Outsider Conflict}

An interesting aspect of the Organizational Revolution is that it tends to give more scope for earnings to be determined by factors that cannot be captured within the conventional supply-demand framework under perfect competition and perfect information. Two alternative frameworks are particular useful in this regard: efficiency wages and “insider-outsider" frameworks.

The idea underlying the efficiency wage framework is simple. ${ }^{75}$ When managers have imperfect information about their employees' actual productivities, they cannot make wages precisely contingent on these productivities, and they often find it worthwhile to use their wage offers as a device for stimulating their employees' performance. Thus a firm offering high wages, relative to its competitors, may induce its employees to work hard or it may attract and retain people of particularly high ability. Similarly, when managers are in the dark about their employees' loyalty, they may set wages so as to induce their employees to stay at their jobs, and thereby saving the firm the costs of hiring and training new recruits.

The upshot is that when a firm raises the wages it pays, it not only increases its wage bill, but it also stimulates productivity and reduces labor turnover costs. On this account, firms have an incentive to minimize not the actual wages they pay, but rather the "efficiency

\footnotetext{
${ }^{75}$ See, for instance, Phelps (1994), Stiglitz (1985), Shapiro and Stiglitz (1984), and Weiss (1980).
} 
wages" (i.e. wages adjusted for productivity). Doing so can drive wages above the level at which labor supply equals labor demand, so that unemployment results. Observe that, unlike the unemployment arising from a wage floor (such as minimum wage legislation), this unemployment does not necessarily fall on the least skilled, lowest paid workers. Rather, the firms' incentive to offer excessive wages is strongest, other things being equal, when employees' performance is most difficult to monitor.

The insider-outsider framework provides a quite different rationale for excessive wages and possible unemployment. ${ }^{76}$ On account of labor turnover costs, it is often expensive for firms to replace their established, incumbent employees ("insiders") by new recruits ("outsiders"). The insiders, knowing this, raise their wage above the level that equalizes labor supply and demand, without running the risk of dismissal, so that unemployment may occur.

The labor turnover costs come in many guises. Whereas some are production-related (i.e. necessary to enable workers to produce goods and services, such as employers' search and screening costs), others are rent-related (i.e. the outcome of rent-seeking activities, such as severance payments and litigation costs associated with firing). A particularly common variety of rent-related turnover costs are those associated with "cooperation activities" (whereby workers support one another in the production process and thereby raise each others' productivities) and "harassment activities" (i.e. interpersonal exchanges in which workers make each others' jobs unpleasant and thereby raise each others' disutility of working). ${ }^{77}$ To protect their wages from being undercut by the outsiders, insiders often have an incentive to cooperate with one another but not with outsiders, and an incentive to harass the underbidding outsiders but not themselves. These activities generate an insider-outsider productivity differential (since the insiders receiving cooperation are more productive than the outsiders who don't) and an insider-outsider differential in reservation wages (since the minimum wages required to induce an harassed outsider to accept the job are lower than those of a non-harassed insider, other things equal). Managers are unable to monitor noncooperation and harassment activities, and thus cannot make wages inversely dependent on them. Thus both the insider-outsider differentials generate labor turnover costs, making it costly for firms to replace their insiders by outsiders and thereby enabling insiders to press for excessive wages and thereby generating unemployment. Once again, the excessive wages

\footnotetext{
${ }^{76}$ See, for example, Lindbeck and Snower (1986, 1987, 1988b).

77 See Lindbeck and Snower (1988a).
} 
and corresponding unemployment are not necessarily associated with the least skilled, lowest paid workers, but rather on employees who work in teams, with lots of opportunities for mutual support or hindrance.

The insider-outsider theory also provides a rationale for the shrinking gender earnings premium. ${ }^{78}$ Up until the early postwar period, women have tended to be the outsiders in the labor market, and men may thus have protected their wages and jobs by using cooperation and harassment activities to keep women out. With affirmative action and changes in social attitudes, women gradually lost their outsider status. As more women entered a particular place of work, the inducement of the existing workforce to keep other women out may well have shrunk.

It is often thought that insider-outsider conflict is relevant primarily to countries with stringent job security legislation and high union density (such as many EU member states), rather than to the U.S., where labor markets are less regulated and unions are less powerful. This view is misguided. Many important types of labor turnover costs (such as those associated with cooperation and harassment activities) are unrelated to job security legislation and union activities. Moreover, some types of labor turnover cost (such as the costs of litigation over unfair dismissal) are particularly common in the U.S. Beyond that, the Organizational Revolution may lead to a leveling of labor turnover costs across many OECD countries - increasing the resistance to centralized wage bargaining in the institutional constrained labor markets while magnifying other labor turnover costs (such as those associated with increasingly idiosyncratic jobs and with cooperation and harassment activities) internationally.

The efficiency wage and insider-outsider frameworks provide an account of earnings inequality that differs significantly from that of the conventional framework. Earnings inequality reflects inequality in productivities (arising from differences in supply and demand under perfect competition and perfect information) in the conventional framework, but it also reflects imperfect information and labor turnover costs in the efficiency wage and insideroutsider frameworks. In the latter two frameworks, therefore, earnings dispersion may exceed productivity dispersion.

In particular, suppose that the higher are people's skill levels, the more difficult it becomes for their employers to monitor them. Then wages increases will generally play a 
larger role in stimulating the productivity of skilled workers than unskilled workers.

Consequently, on top of the rewards for differential productivities, employers have will have an incentive to offer higher wages to their skilled employees than their unskilled ones.

Alternatively, suppose that higher skills, within holistic organizations, are associated with more idiosyncratic jobs and jobs at which there is more scope for cooperation and harassment activities - where the insiders are more difficult to replace by outsiders. Then, quite aside from productivity considerations, the skilled insiders will have an incentive to push for higher wages than their unskilled counterparts.

Thus the Organizational Revolution may generate earnings inequality not only by creating new productivity differentials, but also by (a) turning wages into a more powerful instrument for stimulating productivity and (b) by creating new labor turnover costs. In this context, the rapid increase in earnings inequality in the U.S. and the U.K. over the past two decades and the slower pace of change in other OECD countries may be due not only to differences in institutional wage constraints, but also to differences in the pace of organizational change.

Much hinges on the question of what has driven the rise in earnings inequality changes in productivities (due to shifts in labor demands and supplies), incentive effects (efficiency wages), or insider-outsider considerations. If perfectly competitive forces of supply and demand have played the dominant role, then the increasing earnings inequality may be a largely efficient market response to changing technologies, factor supplies, and consumer preferences. By implication, policies to mitigate earnings inequality are likely to be inefficient, so that a more equal division of the national pie reduces the size of that pie. The policy issue is then how much inequality to tolerate for the sake of an efficient use of our resources.

On the other hand, if incentive effects and insider-outsider considerations have played the dominant role, then the increasing earnings inequality is generally wasteful. When firms use their wage offers to stimulate productivity and employee bonding, wages tend to wind up higher than what would be in the public interest. Similarly, when insiders take advantage of their secure jobs by pushing up their wages, they often hurt the rest of society more than they help themselves. Under these circumstances, it is usually possible to devise policies that not only reduce earnings inequality, but also stimulate efficiency. Then employment vouchers for

\footnotetext{
${ }^{78}$ This idea was suggested to me by Robert Lawrence.
} 
the long-term unemployed, subsidies for low-wage workers, employment-related negative income taxes (such as the Earned Income Tax Credit), and job counseling may, under the appropriate circumstances, both reduce earning inequality and lead to less wasteful uses of our labor resources. ${ }^{79}$

There can be no doubt that the conventional preoccupation with supply and demand under conditions of perfect information and perfect competition has a strong laissez faire bias. Thus the empirical conventional methodology, described above - of examining what part of earnings changes can be ascribed to changes in labor supplies and then attributing the rest to changes in labor demands - is certainly not harmless from a policy perspective. The other common approach (adopted in the first part of this article) - to account for as many empirical regularities as possible through the conventional framework and to use the alternative frameworks only to tackle the remaining empirical observations - is not harmless either. In order to formulate sensible policy guidelines on inequality, economists need to pour a lot more effort into comparative empirical evaluations of the conventional, efficiency wage, and insider-outsider approaches.

\section{The Skill Incidence of Unemployment}

Many of the jobs being generated by the Organizational Revolution - requiring greater degrees of employee discretion, more creativity, more common sense, and greater autonomy in the exercise of diverse skills - are a lot more difficult to monitor than the singlepurpose jobs and well-defined occupations spawned by the Industrial Revolution. Thus, for efficiency wage reasons, restructured firms are often likely to have relatively large incentives to offer high wages to their "skilled" employees (defined in accordance with the new organizational structures) in order to stimulate their productivity and buy their loyalty. Furthermore, since the Organizational Revolution frequently increases the scope for team work, it multiplies the opportunities for cooperation and harassment activities, and these opportunities are likely to fall disproportionately into the hands of the "skilled" insiders, enabling them to raise their wages.

Within this context, it comes as no surprise that the incidence of unemployment in recent years has not fallen exclusively on unskilled workers. The organizational incentives to

\footnotetext{
${ }^{79}$ See, for example, Snower (1994) and Phelps (1997) for a discussion of the first two policies.
} 
"delayer" extensive swaths of middle management have doubtlessly amplified this phenomenon.

\section{The Absence of a Trade-off between Low Earnings and High Unemployment}

The efficiency wage and insider-outsider frameworks can help explain why OECD cross-country comparisons do not reveal any clear trade-off between low earnings and high unemployment. Low earnings are not necessarily a guarantee against high unemployment.

First, a drop in the wages of low earners may not increase employment, since it reduces the incentive of these people to search for jobs. ${ }^{80}$ As shown with the efficiency wage framework, low wages are often associated with low job attachment and consequently high unemployment. This pattern is borne out by the evidence cited above. Furthermore, when wages fall, the low earners have a disproportionately large incentive to "become unemployed" in order to engage in crime.

Second, the less job attachment people have, the greater are the labor turnover costs they need to overcome in order for them to compete effectively with the insiders in the labor market. Consequently, the greater the proportion of such unattached outsiders, the higher the wages that the insiders can claim without risking dismissal. The rise in insiders' wages, in turn, may discourage firms from hiring other workers (who would, in time, turn into insiders themselves). On this account, as well, low wages may be associated with high unemployment.

\section{Some Concluding Thoughts and Worries}

In the conventional account, shifts in labor demand towards skilled and away from unskilled labor are given a major role to play in explaining the widening earnings dispersion. These demand shifts are allegedly driven by technological change and, to a lesser degree, by globalization and deindustrialization. It is an appealing story and, as we have seen, it can account for many observations about earnings inequality: changes in the education premium, the experience premium, various labor supply effects, and the wage effects of some institutional rigidities. But it is harder to explain other observations - changes in the gender premium, earnings instability, within-group inequality, the absence of a trade-off between low earnings and unemployment, and the skill incidence of unemployment - in this way.

\footnotetext{
${ }^{80}$ It will also increase the employers' incentive to find job applicants, but the employment effect of employers' increased search may be dominated by that of the employees' reduced search.
} 
This article has suggested that a network of recent, complementary organizational changes - which we have called the Organizational Revolution - may have important implications for the evolution of inequality in the Western world. These changes may be redefining our conception of "skills" and transforming the rewards people receive for their work. Many of the observations that are difficult to explain conventionally are more easily captured through the salient features of the Organizational Revolution. The direct evidence in favor of this account - like that for the technological change hypothesis - rests on case studies, and the available data are not sufficient to permit a proper statistical appraisal.

The conventional framework continually runs the risk of being tautologous. A prominent feature of the many empirical studies, discussed above, is that any change in inequality that cannot be ascribed to supply is automatically attributed to demand, and "technological change" in particular is usually the residual catchall for any explained movements in earnings. On the basis of the available case studies, one cannot be sure whether all that is usually ascribed to technological change is really associated with changes in production techniques. Thus, even if the conventional framework could account for all the major empirical regularities, it would still rest on largely circumstantial evidence.

Perhaps this worry could be put aside if the conventional framework were the only show in town. But it isn't. There are others - especially the efficiency wage and insider-outsider approaches - that offer competing explanations for the major empirical regularities. It turns out that these approaches have radically different policy implications from the conventional framework. Whereas the conventional supply-demand analysis usually implies that inequality can be reduced only at the expense of economic efficiency, the efficiency wage and insideroutsider approaches imply that equality and efficiency can be promoted simultaneously. From the policy makers' perspective, that's a momentous difference.

We have seen that the efficiency wage and insider-outsider approaches can shed new light on how observed changes in inequality may arise from the Organizational Revolution. But in the absence of further empirical evidence, this line of thinking can be no more than a potentially significant hunch.

If we are indeed in the midst of an Organizational Revolution, what are our prospects? Will the rich in the U.S. continue to get richer while the poor get poorer? It is impossible to say. The repercussions of the Organizational Revolution are doubtlessly as hard to predict 
nowadays as the repercussions of the Industrial Revolution were back in the beginning of the nineteenth century.

All that can be said with some confidence is that the Organizational Revolution does not provide a rationale for the common belief in the New Economy, growing at phenomenal rates, but immune to inflation and unemployment. There is nothing in the recently observed patterns of organizational change - or, for that matter, in the patterns of technological change, globalization, and deindustrialization - that keeps wages and prices steady and guarantees employment for all. The economy will continue to face the twin dangers of overheating and over-capacity. And although the Organizational Revolution is capable of improving economic growth rates for now, sooner or later it will have run its course and we will have to look elsewhere for continued improvements in our living standards. By then, people will no doubt have adjusted their skills, technologies, and preferences to the new economic regime, in much the same way that they adjusted to electricity, railroads, and automobiles. In the meantime, however, earnings inequality is likely to remain a serious social and economic challenge. 


\section{References}

Altonji, Joseph, and David Card, "The Effects of Immigration on the Labor Market Outcomes of Less-Skilled Natives," in John M. Abowd, and Richard B. Freeman (eds.), Immigration, Trade, and the Labor Market, Chicago: University of Chicago Press, 201234.

Appelbaum, Eileen and Rosemary Bott (1994) The New American Workplace, ILR Press, Ithaca, New York.

Atkinson, Anthony, Francois Bourguignon, and C. Morrison (1992), Empirical Studies of Earnings Mobility, Chur, UK: Harwood Academic Publishers.

Autor, D., L. Katz, and A. Krueger, "Computing Inequality: Have Computers Changed the Labor Market?" mimeo, Harvard University.

Berger, Mark (1985), "The Effect of Cohort Size on Earnings Growth: A Reexamination of the Evidence," Journal of Political Economy, June, 93, 201-34.

Berman, Ely, John Bound, and Zvi Griliches (1994), "Changes in the Demand for Skilled Labor with U.S. Manufacturing Industries: Evidence from the Annual survey of Manufacturing," Quarterly Journal of Economics, May, 2, 109.

Berndt, E., C. Morrison, and L. Rosenblum (1992), "High-Tech Capital Formation and Labor Composition in U.S. Manufacturing Industries: An Exploratory Analysis," NBER Working Paper 4010.

Bhagwati, Jagdish, and Vivek Dehejia (1994), "Free Trade and Wages of the Unskilled: Is Marx Striking Again?" in J. Bhagwati and M. Kosters (eds.), Trade and Wages, Washington, D.C.: American Enterprise Institute, 36-75.

Blackburn, M., D. Bloom, and R. Freeman (1990), "The Declining Economic Position of Less-Skilled American Males," in G. Burtless (ed.), A Future of Lousy Jobs? Washington, D.C.: Brookings.

Bound, John, and George Johnson (1992), "Changes in the Structure of Wages in the 1980s: An Evaluation of Alternative Explanations," American Economic Review, June, 371-392.

Card, David (1990), "The Impact of the Mariel Boat-life on the Miami Labor Market," Industrial and Labor Relations Review, January, 40, 382-393.

Cohen, Daniel (1998), The Wealth of the World and the Poverty of Nations, Cambridge, Massachusetts: MIT Press.

Davis, S. (1992), "Cross-Country Patterns of Change in Relative Wages," NBER Macroeconomics Annual, Cambridge: MIT Press, 239-300.

DiNardo, John E., and Jorn-Steffen Pischke (1996), “The Returns to Computer Use Revisited: Have Pencils Changed the Wage Structure Too?" National Bureau of Economic Research, Working Paper No. 5606, June.

DiNardo, John, Nicole M. Fortin, and Thomas Lemieux (1996), "Labor Market Institutions and the Distribution of Wages, 1973-1992: A Semiparametric Approach," Econometrica, September, 65, 1001-44.

Drucker, Peter (1969), The Age of Discontinuity, London: Heineman. 
Edin, Per-Anders, and Bertil Holmlund (1995), "The Swedish Wage Structure: The Rise and Fall of Solidarity Wage Policy?" in Richard B. Freeman and Lawrence F. Katz (eds), Differences and Changes in Wage Structures, Chicago: University of Chicago Press for NBER, 307-44.

European Industrial Relations Review (1992), "The Rise and Fall of Centralized Bargaining," No 220 (April), 20-22.

Filer, Randall, "The Effect of Immigrant Arrivals on Migrating Patterns of Native Workers," in George Borjas and Richard B. Freeman (eds.), Immigration and the Work Force, Chicago: Chicago University Press, 245-269.

Freeman, Richard B. (1980), "Unionism and the Dispersion of Wages," Industrial and Labor Relations Review, October, 34, 3-23.

Freeman, Richard (1988), "Evaluating the European View that the United States has No Unemployment Problem," American Economic Review, Papers and Proceedings, May, 78, 294-299.

Freeman, Richard B. (1993), "How Much as De-Unionization Contributed to the Rise in Male Earnings Inequality?" in S. Danziger and P. Gottschalk, Uneven Tides: Rising Inequality in America, New York: Russell Sage Foundation, 99-164.

Freeman, Richard B. (1995), “Are Your Wages Set in Beijing?” Journal of Economic Perspectives, 9(3), Summer, 15-32.

Freeman, Richard, and Robert Gibbons (1993), "Getting Together and Breaking Apart: The Decline of Centralized Collective Bargaining," Cambridge, Mass: NBER Working Paper No. 4464.

Freeman, Richard, and Lawrence Katz (1994), "Rising Wage Inequality: The United States vs. Other Advanced Countries," in Richard Freeman (ed.), Working Under Different Rules, New York: Russell Sage Foundation.

Goldin, Claudia, and Lawrence F. Katz (1996), "The Decline of Noncompeting Groups: Changes in the Premium to Education, 1890-1940," mimeo.

Gottschalk, Peter (1997), "Inequality, income Growth, and Mobility: The Basic Facts," Journal of Economic Perspectives, 11(2), Spring, 21-40.

Gottschalk, Peter, and Robert Moffitt (1994), "The Growth of Earnings Instability in the U.S. Labor Market," Brookings Papers on Economic Activity, 2, 217-72.

Gottschalk, Peter, and Timothy Smeeding (1996)," "Cross-National Comparisons of Earnings and Income Inequality," Journal of Economic Literature, 35, June, 633-687.

Hammer, Michael and James Champy (1993) Reengineering the Corporations, Harper Business, New York.

Haskel, Jonathan E., and Matthew J. Slaughter (1998), "Does the Sector Bias of Skill-Biased Technical Change Explain Changing Wage Inequality?” Discussion Paper No. 386, April, Economics Department, Queen Mary and Westfield College.

Haskel, Jonathan E., and Ylva Heden (1998), "Computers and the Demand for Skilled Labor: Industry and Establishment-Level Panel Evidence for the UK," Discussion Paper No. 384, April, Economics Department, Queen Mary and Westfield College. 
Hirsch, Barry T., and David Macpherson (1996), Union Membership and Earnings Data book, Compilations from the Current Population Survey, Washington, D.C.: Bureau of National Affairs.

Johnson, George E. (1997), "Changes in Earnings Inequality: The Role of Demand Shifts," Journal of Economic Perspectives, 11(2), Spring, 41-54.

Katz, Harry C. (1993), "The Decentralization of Collective Bargaining: A Literature Review and Comparative Analysis," Industrial and Labor Relations Review, 47 (1), 3-22.

Katz, Harry C., and Thomas A. Kochan (1992), An Introduction to Collective Bargaining and Industrial Relations, New York: McGraw Hill.

Katz, Lawrence, G. Loveman, and D. Blanchflower (1995), “A Comparison of Changes in the Structure of Wages in Four OECD Countries," in Katz and Freeman (eds.), Differences and Changes in Wage Structures, Chicago: University of Chicago Press.

Katz, Lawrence F., and Kevin M. Murphy (1992), "Changes in Relative Wages, 1963-1987: Supply and Demand Factors," Quarterly Journal of Economics, Feb., 107, 35-78.

Katz, Lawrence, and Anna Ravenga (1989), "Changes in the Structure of Wages, the U.S. vs. Japan," Journal of Japanese and International Economics, III.

Kim, Dae-Il, and Robert H. Topel (1995), "Labor Markets and Economic Growth: Lessons from Korea's Industrialization, 1970-1990," in Richard B. Freeman and Lawrence F. Katz (eds), Differences and Changes in Wage Structures, Chicago: University of Chicago Press for NBER, 227-64.

Kremer, Michael and Eric Maskin (1995) "Segregation and the rise in inequality", mimeo.

Krueger, Alan (1993), "How Computers have Changed the Wage Structure: Evidence from Microdata," Quarterly Journal of Economics, 108, 33-60.

Lampman, Robert J. (1971), Ends and Means of Reducing Income Poverty, Chicago: Markham.

Lawrence, Robert Z. (1996), Single World, Divided Nations? International Trade and OECD Labor Markets, Washington, D.C.: Brookings Institution Press.

Leamer (1984), Edward, Sources of International Comparative Advantage, Cambridge: MIT Press.

Levine, I. David and Laura D'Andrea Tyson (1990) "Participation, Productivity and the Firm's Environment", in Blinder.

Levy, Frank, and Richard J. Murnane (1992), "U.S. Earnings Level and Earnings inequality: A Review of Recent Trends and Proposed Explanations," Journal of Economic Literature, Sept, 30(3), 1333-81.

Lewis, H. Gregg (1986), Union Relative Wage Effects, Chicago: University of Chicago Press.

Lindbeck, Assar, and Dennis J. Snower (1986), "Wage Setting, Unemployment, and InsiderOutsider Relations," American Economic Review, Papers and Proceedings, 76(2), 235-239.

Lindbeck, Assar, and Dennis J. Snower (1987), "Efficiency Wages versus Insiders and Outsiders," European Economic Review, February, 31, 407-416. 
Lindbeck, Assar, and Dennis J. Snower (1988a), "Cooperation, Harassment, and Involuntary Unemployment," American Economic Review, March, 78(1), 167-188.

Lindbeck, Assar, and Dennis J. Snower (1988b), "Job Security, Work Incentives, and Unemployment," Scandinavian Journal of Economics, 90(4), 453-474.

Lindbeck, Assar, and Dennis J. Snower (1995), "Restructuring Production and Work," Discussion Paper No. 12/95, Department of Economics, Birkbeck College, University of London.

Lindbeck, Assar, and Dennis J. Snower (1996a), "Reorganization of Firms and Labor Market Inequality," American Economic Review, May, 86(2), 315-321.

Lindbeck, Assar, and Dennis J. Snower (1996b), "Centralized Bargaining, Multi-Taking, and Work Incentives," Seminar Paper No. 620, Institute for International Economic Studies, Stockholm University.

Lindbeck, Assar, and Dennis J. Snower (1997), "The Division of Labor Within Firms," Seminar Paper No. 628, Institute for International Economic Studies, Stockholm University.

Locke, Richard M. (1992), "The Decline of the National Union in Italy: Lessons for Comparative Industrial Relations Theory," Industrial and Labor Relations Review, 45(2), 229-49.

Machin, Stephen (1996), "Changes in the Relative Demand for Skills," in Acquiring Skills, ed. by Alison Booth and Dennis J. Snower, Cambridge: Cambridge University Press, 127146.

Machin, Stephen, and Alan Manning (1994), "Minimum Wages, Wage Dispersion and Employment: Evidence from the UK Wages Councils," Industrial and Labor Relations Review, 47, 319-329.

Machin, Stephen, and John Van Reenen (1998), "Technology and changes in Skill Structure: Evidence from Seven OECD Countries," mimeo, Department of Economics, University College London, April.

Marginson, Paul, et al. (1988), Beyond the Workplace: Managing Industrial Relations in Multi-Establishment Enterprises, Oxford: Blackwell.

Milgrom, Paul and John Roberts (1990) "The Economics of Modern Manufacturing. Technology, Strategy and Organization", American Economic Review, pp. 511-528.

Millward, N., and M. Stevens (1986), British Workplace Industrial Relations 1980-1984, Aldershot: Gower.

Millward, N., et al. (1992), Workplace Industrial Relations in Transition, Brookfield:

Darmouth University Press.

Mincer, Jacob (1989), "Human Capital Responses to Technical Change,” NBER Working Paper No 3207.

Mincer, Jacob (1991), "Human Capital, Technology, and the Wage Structure: What Do the Time Series Show?” NBER Working Paper 3581.

Mishel, L., and J. Bernstein (1994), The State of Working America, 1994-95, New York:

M.E. Sharpe. 
Mitchell, Daniel J.B., David Lewin, and Edward E. Lawler III (1990), "Alternative Pay Systems, Firm Performance, and Productivity," in Paying for Productivity: A Look at the Evidence, ed. by Alan S. Blinder, Washington, D.C.: The Brookings Institution.

Murnane, richard, John Willet, and Frank Levy (1995), "The Growing Importance of Cognitive Skills in Wage Determination," Review of Economics and Statistics, 77(2), 251266.

Murphy, Kevin, and Finis Welch (1993), "Industrial Change and the Rising Importance of Skill," in Peter Gottschalk and Sheldon Danziger (eds.), Uneven Tides, New York: Russell Sage Foundation, 101-132.

Nickell, Stephen, and Brian Bell (1995), "The Collapse in Demand for the Unskilled and Unemployment Across the OECD," Oxford Review of Economic Policy, 11(1), 40-62.

Nickell, Stephen, and Brian Bell (1996), "Would Cutting Payroll Taxes on the Unskilled Have a Significant Impact on Unemployment" in Unemployment Policy, ed. by Dennis J. Snower and Guillermo de la Dehesa, Cambridge: Cambridge University Press, 296-328.

NUTEK (1996), Towards Flexible Organisations, Stockholm: Swedish National Board for Industrial and Technical Development.

OECD (1994), Background Document for a Study of Economic and Other Linkages with Major Developing Countries, Aug., Paris: OECD.

OECD (1996), "Earnings Inequality, Low-Paid Employment and Earnings Mobility," Employment Outlook, July, ch. 3, 59-108.

Parker, Mike, and Jan Slaughter (1988), Changing Sides: Unions and the Team Concept, Boston: South End Press.

Pfeiffer, Jeffrey (1994) Competitive Advantage through People, Harvard Business School Press, Boston, Mass.

Phelps, Edmund S. (1994), Structural Slumps: The Modern Equilibrium Theory of Unemployment, Interest and Assets, Cambridge, Mass: Harvard University Press.

Phelps, Edmund S. (1997), Rewarding Work, Cambridge: Harvard University Press.

Phelps, Edmund, and Gylfi Zoega (1996), "The Incidence of Increased unemployment in the Group of Seven, 1970-1994," Discussion Paper No. 21/96, Department of Economics, Birkbeck College, University of London.

Piore, Michael J. and F. Sabel (1984), The Second Industrial Divide, Possibilities for Prosperity, Basic Books, New York.

Shapiro, Carl, and Joseph E. Stiglitz (1984), "Equilibrium Unemployment as a Worker Discipline Device," American Economic Review, 74(3), 433-444.

Snower, Dennis J. (1994), "Converting Unemployment Benefits into Employment Subsidies," American Economic Review, 84(2), 65-70.

Stiglitz, Joseph E. (1985), "Equilibrium Wage Distributions,” Economic Journal, 95, 379, 595-618.

Thelen, Kathleen A. (1991), Union of Parts: Labor Politics in Postwar Germany, Ithaca, New York: Cornell University Press. 
Topel, Robert H. (1993)., "Regional Labor Markets and the Determinants of Wage Inequality," American Economic Review, Papers and Proceedings, May, 83, 110-15.

Turner, Lowell (1991), Democracy at Work: Changing World Market and the Future of Unions, Ithaca, New York: Cornell University Press.

Weiss, Andrew (1980), "Job Queues and Layoffs in Labor Markets with Flexible Wages," Journal of Political Economy, 88, 526-538.

Welch, Finis (1979), “The Effects of Cohort Size on Earnings: The Baby Boom Babies' Financial Bust," Journal of Political Economy, October, 87, 865-897.

Wikström, Solveig and Richard Norman (1994) Knowledge and Value, Routledge, London. Windolf, Paul (1989), "Productivity Coalitions and the Future of Corporatism," Industrial Relations, 28 (Winter), 1-20.

Wood, Adrian (1994), North-South Trade, Employment and Inequality, Oxford: Clarendon Press. 